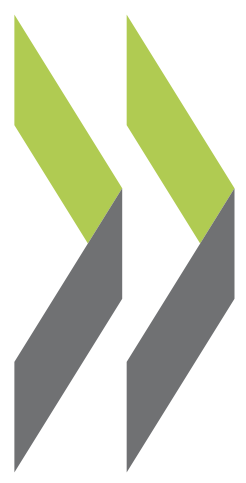

OECD Economics Department Working Papers No. 1124

Making the Labour Market

Work Better in Poland

Hervé Boulhol

https://dx.doi.org/10.1787/5jz2pwf4wd41-en 
Organisation de Coopération et de Développement Économiques

Organisation for Economic Co-operation and Development

04-Jun-2014

ECONOMICS DEPARTMENT

English - Or. English

\section{MAKING THE LABOUR MARKET WORK BETTER IN POLAND}

ECONOMICS DEPARTMENT WORKING PAPERS No. 1124

By Hervé Boulhol

OECD Working Papers should not be reported as representing the official views of the OECD or of its member countries. The opinions expressed and arguments employed are those of the author.

Authorised for publication by Alvaro Pereira, Director, Country Studies Branch, Economics Department.

All Economics Department Working Papers are available through OECD's Internet website at http://www.oecd.org/eco/workingpapers

JT03358730

Complete document available on OLIS in its original format

This document and any map included herein are without prejudice to the status of or sovereignty over any territory, to the delimitation of international frontiers and boundaries and to the name of any territory, city or area. 
ECO/WKP(2014)20

OECD Working Papers should not be reported as representing the official views of the OECD or of its member countries. The opinions expressed and arguments employed are those of the authors.

Working Papers describe preliminary results or research in progress by the authors and are published to stimulate discussion on a broad range of issues on which the OECD works.

Comments on Working Papers are welcomed, and may be sent to OECD Economics Department, 2 rue André-Pascal, 75775 Paris Cedex 16, France, or by e-mail to eco.contact@oecd.org

This document and any map included herein are without prejudice to the status of or sovereignty over any territory, to the delimitation of international frontiers and boundaries and to the name of any territory, city or area.

The statistical data for Israel are supplied by and under the responsibility of the relevant Israeli authorities. The use of such data by the OECD is without prejudice to the status of the Golan Heights, East Jerusalem and Israeli settlements in the West Bank under the terms of international law. multimedia products in your own documents, presentations, blogs, websites and teaching materials, provided that suitable acknowledgment of OECD as source and copyright owner is given. All requests for commercial use and translation rights should be submitted to rights@oecd.org. 
ECO/WKP(2014)20

\section{ABSTRACT/RÉSUMÉ}

\section{Making the labour market work better in Poland}

Poor labour-market outcomes remain one of Poland's major structural weaknesses, impeding firms' competitiveness and the nation's potential output. Boosting employment prospects is also critical, as the country will soon be ageing at a fast pace. Despite long working hours, labour utilisation is only average due to structurally low employment rates, particularly at both ends of the age spectrum, with some marked regional differences. The female employment rate is especially low, in part due to poorly designed family and pension policies. Insufficient product-market competition and obstacles to internal mobility induce significant resource misallocation. Employment protection is not particularly stringent, but the labour market is nonetheless heavily segmented. This is likely to weigh on economic performance by limiting investment in human capital and making some specific groups bear a large share of adjustment costs. Public employment services suffer from a lack of resources and function inefficiently. Local labour offices have limited incentives to adopt best practices; the government plans to start benchmarking them. There is ample scope to tighten jobseeker obligations and reform social and tax policies to make work pay. This Working Paper relates to the 2014 OECD Economic Survey of Poland (www.oecd.org/eco/surveys/economic-survey-poland.htm).

JEL classification codes: J01, J08, J13, J21, J24, J26, J31, J65

Keywords: labour market, employment, unemployment, labour market policies, employment protection, employment services, education, pensions

\section{$* * * * * * *$}

\section{Améliorer le fonctionnement du marché du travail en Pologne}

Les résultats médiocres obtenus sur le front de l'emploi restent une des principales faiblesses structurelles de la Pologne, entravant la compétitivité des entreprises et la production potentielle du pays. Il est également crucial d'améliorer les perspectives d'emploi dans la mesure où la population va bientôt vieillir rapidement. Malgré le nombre élevé d'heures travaillées, le niveau d'utilisation de la main-d'œuvre est seulement moyen en raison de la faiblesse structurelle des taux d'emploi, en particulier aux deux extrémités de l'échelle des âges, avec des différences régionales marquées. Le taux d'emploi des femmes est particulièrement bas, ce qui tient en partie aux défauts de conception des politiques familiales et du système de retraite. L'insuffisance de la concurrence sur les marchés de produits et les obstacles à la mobilité interne se traduisent par des problèmes importants d'affectation des ressources. La protection de l'emploi n'est pas particulièrement rigoureuse, mais le marché du travail n'en demeure pas moins fortement segmenté. Cela pèse probablement sur les performances de l'économie, en limitant l'investissement dans le capital humain et en faisant assumer à certains groupes une part importante des coûts d'ajustement aux chocs économiques. Les services publics de l'emploi pâtissent d'un manque de ressources et fonctionnent de manière inefficace. Les agences locales de l'emploi ne sont guère incitées à adopter les meilleures pratiques; le gouvernement projette de commencer à les soumettre à des évaluations comparatives. Les autorités disposent d'amples marges de manœuvre pour durcir les obligations imposées aux demandeurs d'emploi et réformer les politiques sociales et fiscales de manière à valoriser le travail. Ce Document de travail se rapporte à l'Étude économique de l'OCDE de la Pologne 2014 (www.oecd.org/fr/eco/etudes/etude-economique-pologne.htm).

Classification JEL : J01, J08, J13, J21, J24, J26, J31, J65

Mots clefs : marché du travail, emploi, chômage, politiques du marché du travail, protection de l'emploi, services de l'emploi, éducation, pensions 


\section{Table of contents}

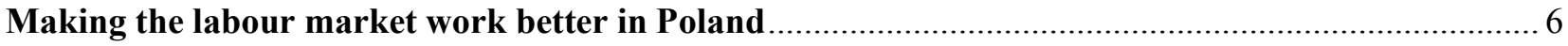

Boosting employment performance is key to enhancing Poland's economic prospects ......................... 6

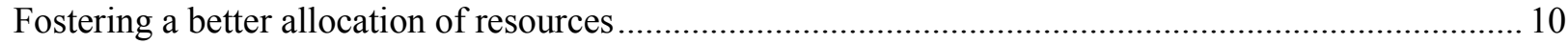

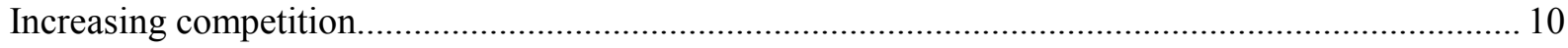

Removing impediments to internal labour mobility ......................................................................... 10

Reducing the distortions generated by the farmers' social insurance system (KRUS) ........................ 11

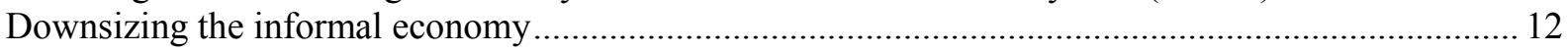

Labour-market policies to improve overall employment …............................................................ 13

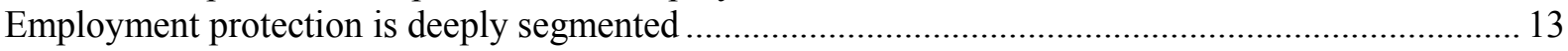

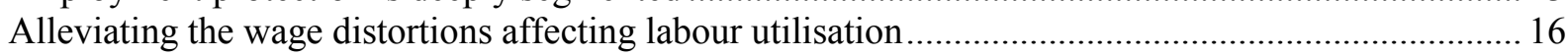

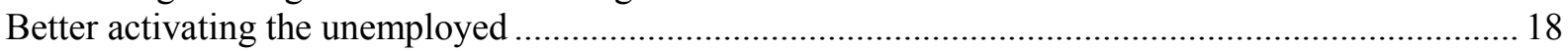

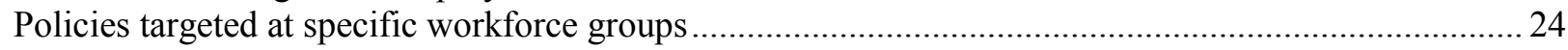

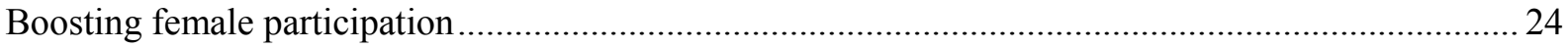

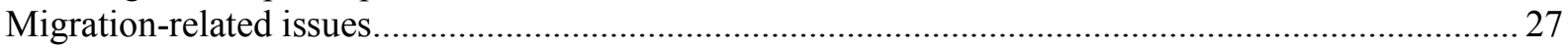

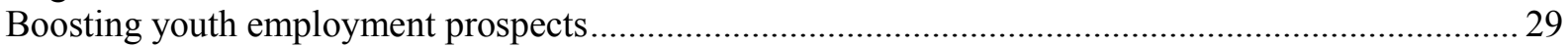

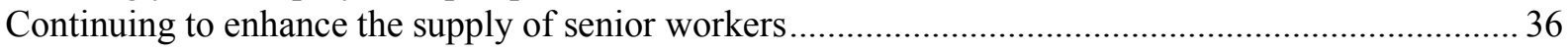

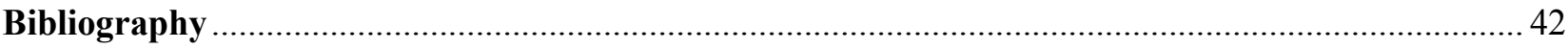

Box

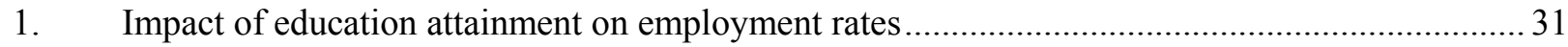

\section{Tables}

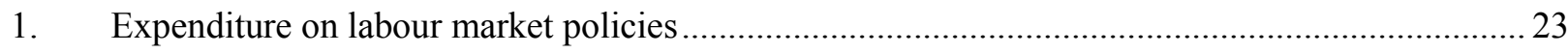

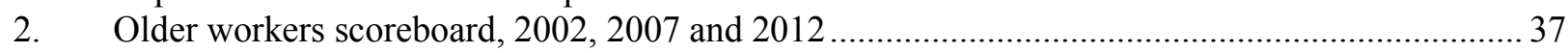

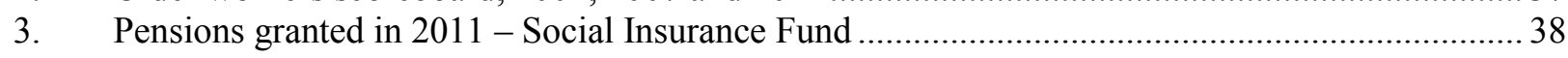

\section{Figures}

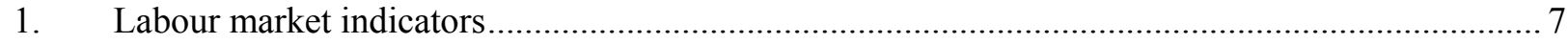

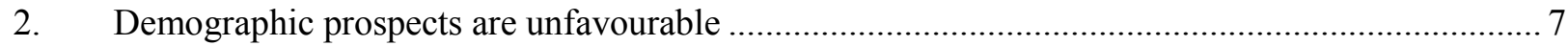

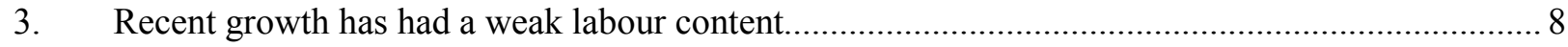

4. Employment rates are especially low at both ends of the age spectrum, 2012 …........................9

5. Older workers' participation rates are low, especially for the low-educated in remote areas ........ 10

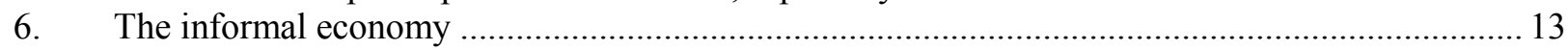

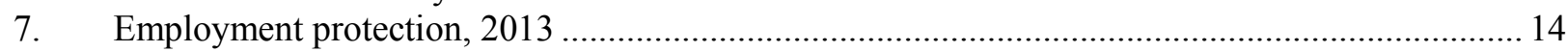

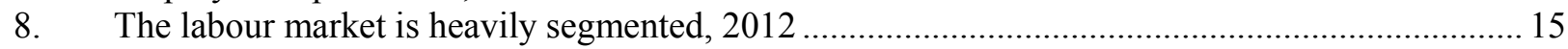

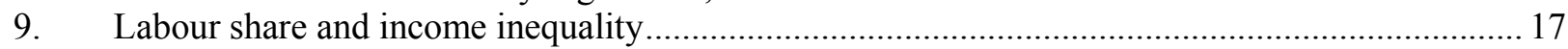

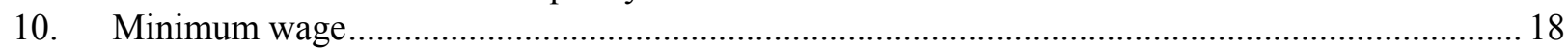

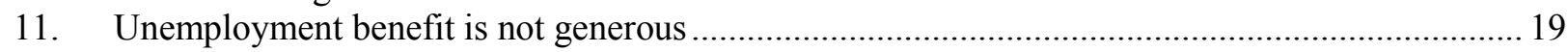

12. Overall net replacement rates are high only for those on low wages ..........................................2 20 
13. The average tax wedge is slightly above OECD average, while the marginal tax wedge is lower,

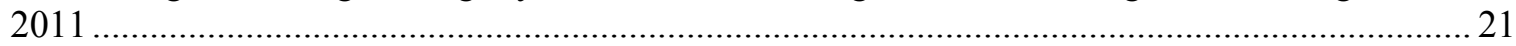

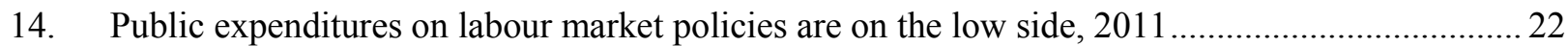

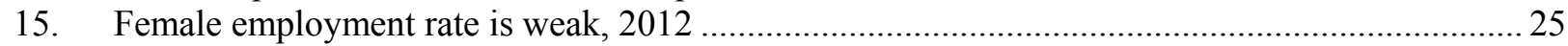

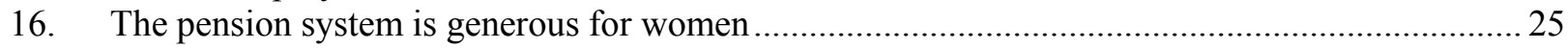

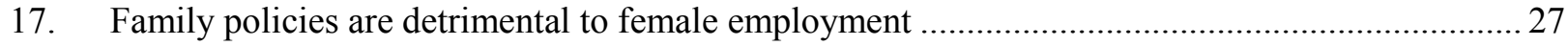

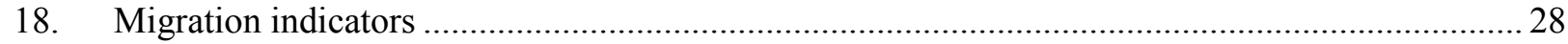

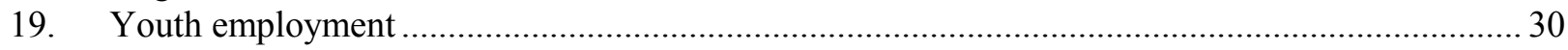

20. Educational attainment shapes employment prospects relatively heavily ................................... 31

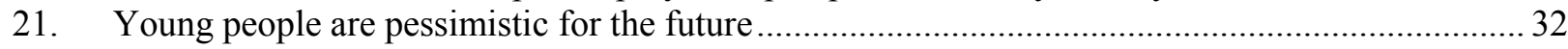

22. Youth unemployment rates are deeply affected by cyclical developments................................. 32

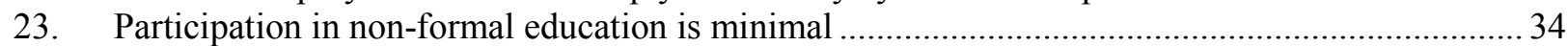

24. Enrolment rate in pre-primary education is rising but remains low ............................................ 35

25. Employment and participation rates for older workers have increased from low levels............... 36

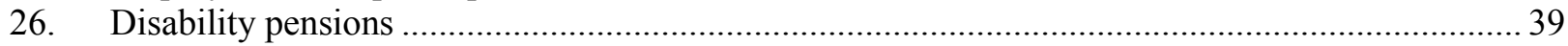




\title{
Making the labour market work better in Poland
}

\author{
By \\ Hervé Boulhol ${ }^{1}$
}

\section{Boosting employment performance is key to enhancing Poland's economic prospects}

Employment remains one of Poland's major structural weaknesses, impeding firms' competitiveness and the nation's potential output. The total employment rate, at $59.7 \%$ in 2012, is one of the lowest among OECD countries, resulting from both low labour-force participation and high unemployment (Figure 1). Poland ranks better in terms of labour utilisation measured as total hours worked per capita, close to the average of the top half of OECD countries in terms of GDP per capita (the metric used in Going for Growth), thanks to long average hours worked per employee, which are $23 \%$ greater than this top half average. All the main priorities for structural reforms identified by the OECD in its Going for Growth exercise (product-market competition, the tax structure and welfare system, infrastructure, education and housing) are relevant to enhancing labour market performance. Boosting employment prospects is also critical, because the country will be facing strong demographic shrinkage, given its low fertility rates and fast population ageing (Figure 2). The Central Statistical Office projects that between 2010 and 2035 total and working-age population will fall by $6 \%$ and $16 \%$, respectively.

While the participation rate had fallen steadily between the beginning of the transition period and 2007, it has since increased by 31/2 percentage points (Figure 1, Panel D). Beyond the favourable impact of relatively strong growth, the recent improvement in participation has been triggered by diminished accessibility to early-retirement and disability pensions, cohort effects related to the baby boom of the 1980s and a decrease in the labour tax wedge towards the OECD average level (OECD, 2012a).

The 2012-13 slowdown has left its mark on the labour market. The standardised unemployment rate rose as high as $10.6 \%$ in March 2013, up from a record low of $7.1 \%$ in 2008 when the economy was overheating (Figure 3). The strong growth in 2010-11 was insufficient to absorb the rise in participation, and the unemployment rate continued to rise. While the working-age population increased from 2008 to

1. Hervé Boulhol was senior economist in Country Studies Branch in the Economics Department of the OECD (e-mail: herve.boulhol@oecd.org). He is now senior economist in the Social Policy Division in the Directorate for Employment, Labour and Social Affairs. This paper was prepared for the OECD Economic Survey of Poland published in March 2014 under the authority of the Economic and Development Review Committee. The author is grateful to Patrizio Sicari for excellent statistical support. The author is particularly thankful to numerous colleagues for their valuable comments, including Peter Jarrett and Andrea Bassanini, Yuri Belfali, Andrew Dean, Robert Ford, Antoine Goujard, Andrzej Kwiecinski, Thomas Liebig, Hilde Olsen, Glenda Quintini, Angelica Salvi del Pero and Anne Sonnet, as well as to Polish government and central bank officials. Special thanks are due to Mee-Lan Frank for excellent technical preparation. 
Figure 1. Labour market indicators, 2012
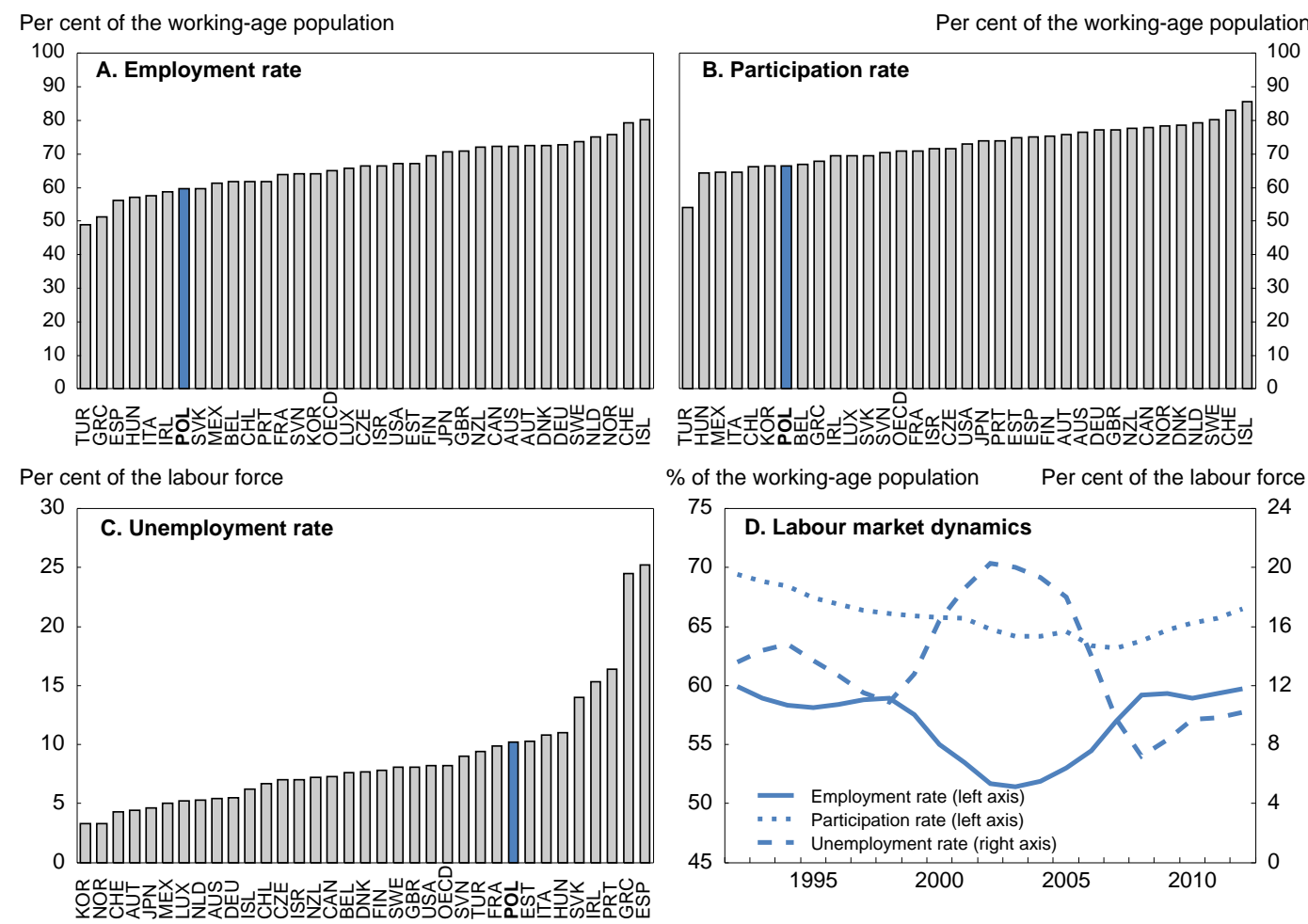

Source: OECD, Labour Force Statistics 2013 database.

Figure 2. Demographic prospects are unfavourable

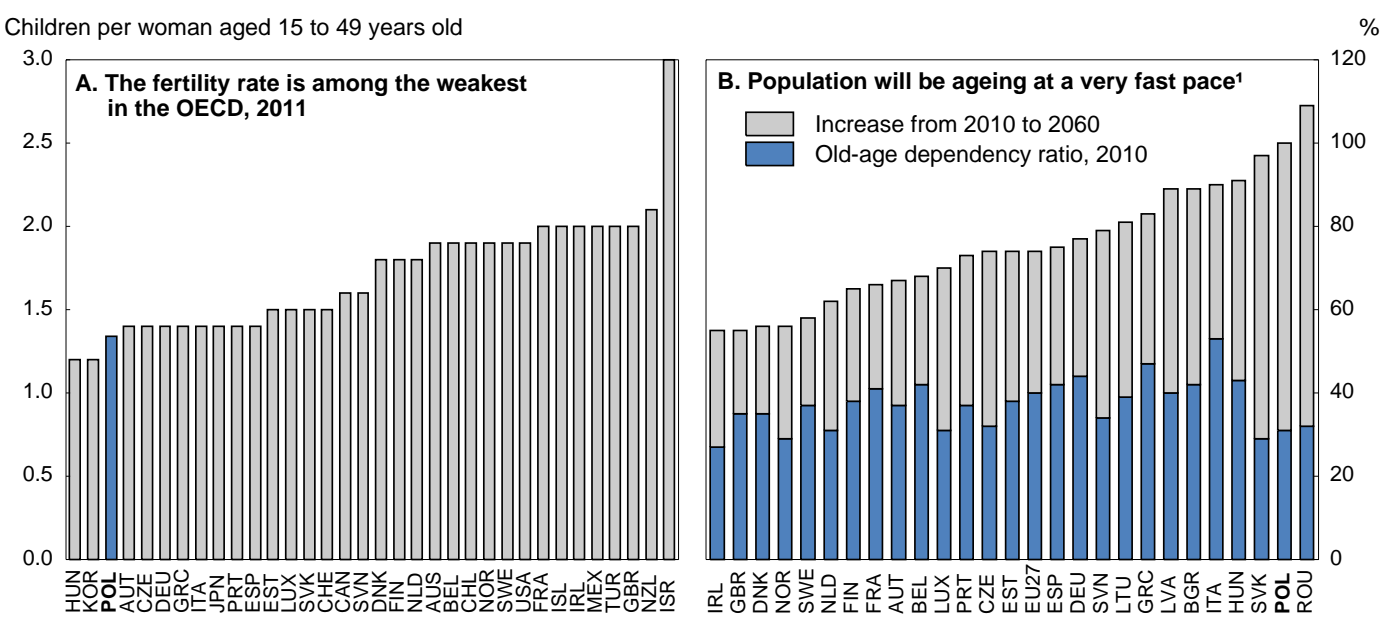

1. Effective economic old-age dependency ratio, measured as inactive population aged 65 and over as a ratio to the 20-64 employed population.

Source: OECD, Population Statistics and OECD Health indicators; European Commission (2012), The 2012 Ageing Report. 
Figure 3. Recent growth has had a weak labour content
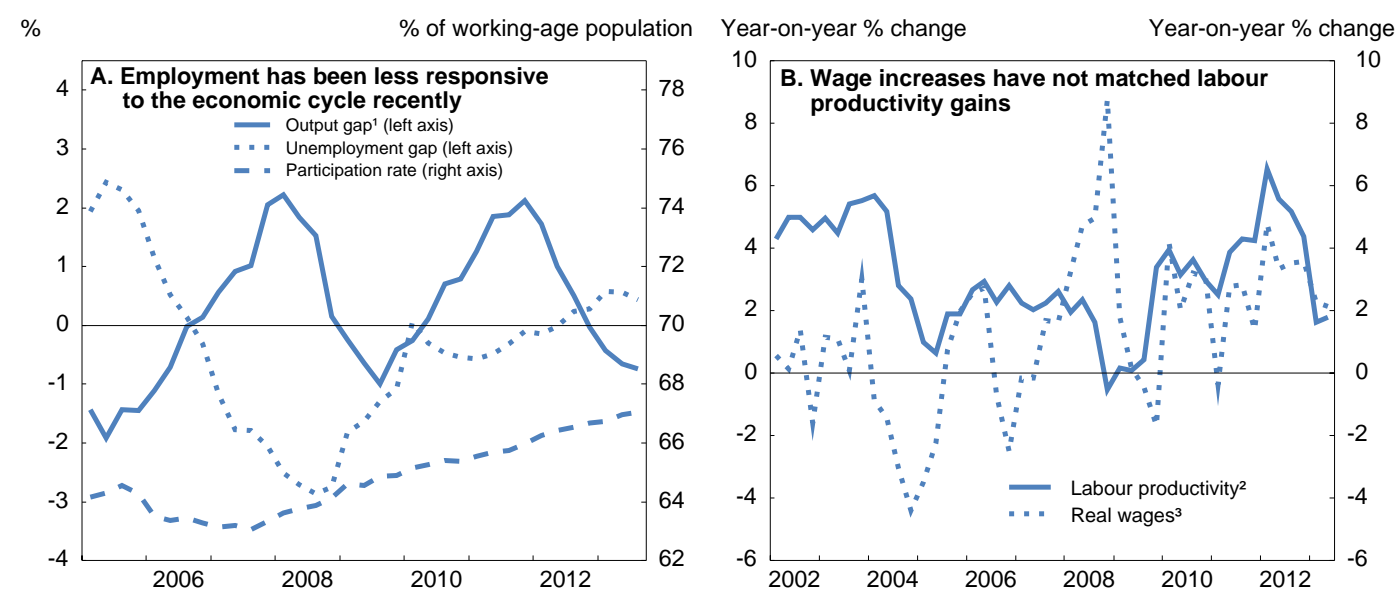

1. As a percentage of potential GDP.

2. Labour productivity is measured as real GDP per worker.

3. Dependent employment.

Source: OECD, Economic Outlook 94 database.

How to read this figure: The output gap measures the difference between the level of real GDP and its potential. Hence, a positive output gap indicates that real GDP exceeds its potential, which is likely to trigger inflationary pressure, and conversely a negative gap should put downward pressure on inflation. The unemployment gap measures the difference between the unemployment rate and its estimated equilibrium level (NAIRU). The unemployment gap is an important component of the output gap, and a positive unemployment rate gap tends to be associated with a negative output gap (and vice versa). But this is not always the case, as the output gap is also influenced by other components such as deviations from trends in total factor productivity and labour force participation. The chart shows that in the 2007-08 boom employment was very responsive to the economic cycle, and the unemployment rate fell below its equilibrium level as real GDP increasingly exceeded its potential level. However, in 2011 the employment response to the acceleration in activity was relatively muted, in part due to the increase in labour supply as reflected by the higher participation rate.

2012 by 202000 people $(0.7 \%)$, the labour force surged by $846000(+5.1 \%)$, comprising rises of 273000 in total employment $(+1.8 \%)$ and 573000 in unemployment. The latest unemployment rate $(10.2 \%)$ is close to the OECD estimate of the NAIRU (Non-Accelerating Inflation Rate of Unemployment) level $(10.0 \%)$, which remains one of the highest within the OECD. This suggests that the high level of unemployment is essentially structural, although current low inflation could mean that the NAIRU is overestimated, implying some slack in the labour market.

Poland's poor labour-market performance is due to particularly low employment rates at both ends of the age spectrum (Figure 4), with some marked regional differences. While the age structure of a country's employment rates is typically hump-shaped, with higher employment rates for prime-age people, Poland has a particularly marked hump (Panel D), translating into a high dispersion of employment rates across age groups (Boulhol and Sicari, 2013a). Limited labour supply is reflected in depressed participation rates for workers aged between 55 and 64 (between 35\% and 50\% in 2012, depending on the region). Moreover, the employment rate of older workers is especially weak for the less educated, and below $20 \%$ in some areas (Figure 5). More generally, the employment rate of workers with poor educational attainment is low overall and extremely low in some parts of the country. For example, for those aged between 25 and 34 with less than upper-secondary education, the range was from $37.5 \%$ in Kujawsko-Pomorskie to $57 \%$ in both Lubuskie (bordering Germany) and Malopolskie (bordering the Slovak Republic) in 2012

The specific labour market policy response to the crisis, which was in effect only between August 2009 and December 2011, was primarily aimed at limiting its impact on dismissals. The regulation of fixed-term contracts (FTCs) was modified and that of working time became more flexible. First, the 
Labour Code clause stipulating that only two consecutive FTCs were allowed, implying that a subsequent one was deemed permanent, was suspended. Moreover, following a decade-long debate (hence unrelated to the economic slowdown), a 24-month cap was introduced to the duration of FTCs. Second, the reference period for computing working time was extended from 4 to 12 months, a period during which employees could work shorter or longer weeks (without being paid overtime as long as total hours are below a specific threshold). This allowed for a better smoothing of the impact of economic fluctuations. Third, within the working day, starting and finishing times were also made more flexible. Fourth, employers experiencing temporary financial difficulties were provided with funding facilities and were allowed to reduce working time by up to $50 \%$ for a maximum of six months and were eligible for state assistance to partly compensate employees for lost income and training costs. However, this short-time work scheme was little used, because economic difficulties were relatively mild ex post and because the criterion used to define eligible firms (namely a fall of $25 \%$ in annual turnover) was too strict. Finally, spending on active labour market policies (ALMPs) was scaled up in 2009-10 to $0.45 \%$ of GDP per year, double the 2008 share. With the recent growth slowdown, the government implemented new measures in May 2013, providing direct financial assistance (de minimis aid) to employers experiencing a decrease in turnover.

Figure 4. Employment rates are especially low at both ends of the age spectrum, 2012

As a percentage of the population by age bracket
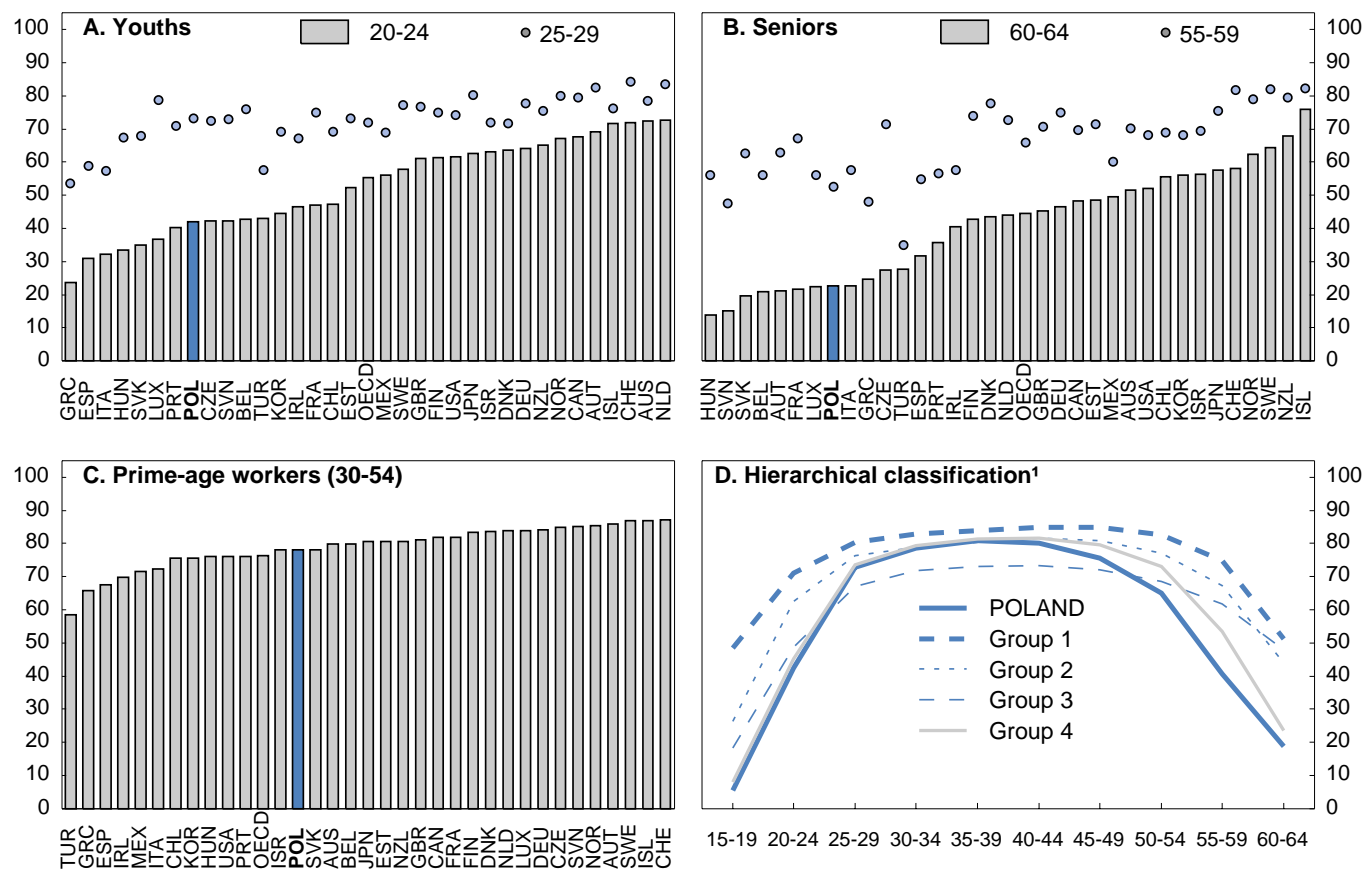

1. A ranked classification was used to identify groups of OECD countries by the structure of employment rates by cohort; 2005-2011 average. Group 1: AUS, CAN, GBR, DNK, NLD, ISL, NZL, NOR, CHE; group 2: AUT, FIN, DEU, JPN, SWE, IRL, USA, MEX; group 3: CHL, ISR, KOR; group 4: BEL, LUX, POL, SVN, GRC, ESP, HUN, ITA, SVK, CZE, FRA, EST and PRT.

Source: OECD, Labour Force Statistics 2013 database and OECD calculations. 
Figure 5. Older workers' participation rates are low, especially for the low-educated in remote areas

As a percentage of the $55-64$ population

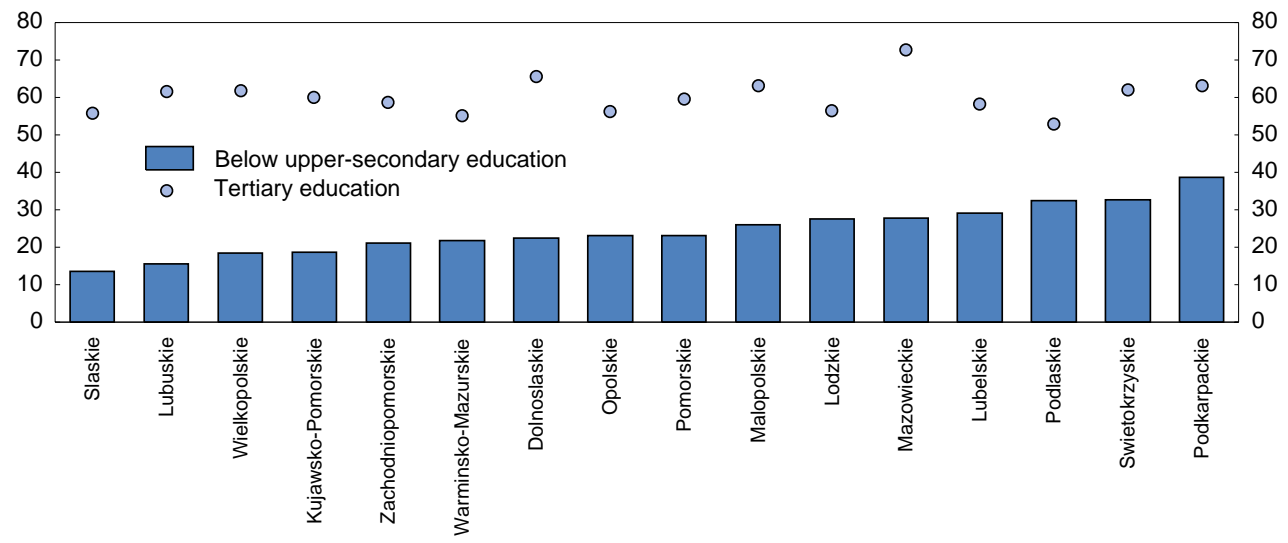

Source: GUS.

This working paper highlights first the employment obstacles that extend beyond the realm of labour market policies. Indeed, a number of inefficiencies induce some substantial misallocation and waste of labour resources. Then, labour market policies to improve overall employment opportunities are discussed. The last part focuses on measures targeted at specific workforce groups.

\section{Fostering a better allocation of resources}

\section{Increasing competition}

Excessive product market regulation hinders productivity gains and the efficient allocation of resources both across firms within sectors and between sectors. It also affects job market performance. By expanding output, product market deregulation tends to boost aggregate labour demand, at least over the medium term, even though employment within the deregulated sectors might decline depending on the price-elasticity of sectoral demand (and therefore on substitution effects across consumed goods) (Fiori et al., 2012; Griffith et al., 2007). The most obvious depressive effects of product market regulations on employment are generated by barriers to entrepreneurship and administrative burdens. The broad reform undertaken by the Polish government to liberalise a large number of professions is thus likely to increase employment, but much more can be done to enhance competition: product market reforms should still feature prominently on Poland's employment-boosting agenda (see Égert and Goujard, 2014).

\section{Removing impediments to internal labour mobility}

Regional differences in employment outcomes persist due to wage rigidities and impediments to labour mobility. The unemployment benefit system is more generous in high-unemployment districts (powiats), thereby potentially limiting internal migration flows towards more dynamic areas, whereas the minimum wage is undifferentiated across regions, despite differences in employment prospects, living costs and productivity. Moreover, in some cases social assistance provides high replacement rates (raising reservation wages), which are often not conditional on active job-search efforts (see below).

On top of this, the insufficient, though improving, quality of transport infrastructure prevents workers from commuting easily and responding to more favourable labour market conditions elsewhere. Indeed, despite some recent noticeable progress in developing road infrastructure, mostly financed by EU funds, internal labour mobility is still widely seen as insufficient, due in large part to the vastly underdeveloped railway system. Only $36 \%$ of railway lines in operation are in good technical condition (European 
Commission, 2013). The absorption of EU funds dedicated to modernising rail infrastructure has proved difficult, due to severe weaknesses in the governance of the state-owned incumbent operator (PKP SA) (Égert and Goujard, 2014). The government investigated the possibility of reallocating a quarter of the dedicated funds to road construction, even though only $25 \%$ of the 2007-13 related programmes was initially allocated to rail (versus 57\% for road), but the European Commission did not allow it. For the 2014-20 period, priority has to shift decisively towards upgrading rail infrastructure, as well targeted investments in this area will yield high returns beyond reducing greenhouse gas emissions.

The functioning of the housing market was analysed in depth in the 2008 Survey (OECD, 2008a; Kierzenkowski, 2008). Expensive housing in urban areas related to weak housing policies is a severe obstacle to relocating and thus to a better integrated national labour market. Poland is one of the OECD countries with the lowest housing per capita (Andrews et al., 2011a). Moreover, the high share of owner occupancy tends to reduce mobility. In 2013 the government submitted to the parliament an amendment that would introduce a voucher that would help people under 30 years old to cover housing expenses upon accepting a job offer involving a change in residence. However, no clear progress has been made in addressing the lack of supply in the private urban rental market. In 2010 the government lifted some rent restrictions for subletting and generalised the lower $8.5 \%$ tax rate on rental income to curb the informal rental market. Efforts should focus on the following actions set out in Going for Growth (OECD, 2013a). The release of zoning plans by municipalities should be made mandatory, as their absence generates lengthy administrative procedures and encourages local corruption. Taxes on housing purchases should be replaced by ad valorem property taxes. On the other hand, compulsory escrow accounts to protect buyers' advances in case of developer bankruptcy were introduced in 2012, consistent with OECD's recommendations. Finally, rent controls and tenants' protection should be further relaxed.

\section{Reducing the distortions generated by the farmers' social insurance system (KRUS)}

The KRUS was established in 1991 to provide low-income farmers with the same level of pensions and social benefits as people under the general social security system (ZUS), but for a much lower contribution. It has become a permanent source of income for farmers and their families, because of benefit sharing, as well as an implicit subsidy to agriculture, thereby slowing consolidation in the sector. In 2007, the average size of a Polish farm was about half that of farms in the European Union, and only $1 \%$ of farms were larger than 50 ha as against 5\% in the EU27 and 11\% in the EU15. However, things have improved since then, with the number of Polish farms being reduced by $16 \%$ between 2007 and 2010. Yet, agriculture still accounts for about $12.5 \%$ of total employment. Overall, the KRUS allows some low-productivity workers to remain in rural areas. Furthermore, with its labour productivity reaching only $16 \%$ of the EU15 level, Poland's agricultural sector is the least productive of all European OECD members.

Two laws that came into force in January 2013 will generate marginal changes. Health-care contribution rates for so-called special agricultural production activities were increased, but remain small; the possibility to benefit from early retirement (women at 55, men at 60) will be gradually eliminated; and the disincentive to undertake a non-farm job for farmers receiving disability benefits is being reduced. On the other hand, a new pre-retirement allowance was introduced for women and men aged 62 and 65, respectively, amounting to half the regular farmers' pension. Clearly, much more is needed. Accession to the EU in 2004 and thus eligibility for the Common Agricultural Policy (CAP) regime and the Structural and Cohesion Funds should have been an attractive opportunity to phase out the KRUS. Indeed, excluding KRUS expenditures but including CAP transfers, the share of agriculture in state budgetary expenditure increased from an average of $2.2 \%$ in $1997-2003$ to $7.4 \%$ in $2008-10$, with the application of CAP instruments alone having doubled farmers' real incomes (Nurzynska, 2012). Special rules regarding KRUS eligibility based on land ownership and the nature of the farming activity should be abolished, and treatment under the KRUS and the ZUS should converge steadily. 


\section{Downsizing the informal economy}

Poland has been identified as one of the OECD countries where informal employment poses the most serious challenges (OECD, 2008b). According to the broadest study (Bühn et al., 2010, updated by Schneider, 2013), the shadow economy represents about $24 \%$ of Polish GDP, behind only Estonia, Turkey and Mexico among OECD countries. However, the methodology used in these widely referenced papers is subject to serious limitations, potentially leading to upward biases (Andrews et al., 2011b). In contrast, according to estimates by the Central Statistical Office (GUS), the shadow economy was about $13 \%$ of GDP in 2010, while the number of people admitting to informal work decreased from $9.6 \%$ of total employment in 2004 to 4.6\% in 2010. Nevertheless, according to Andrews et al. (2011b), based on various proxies, the size of the informal economy is probably high relative to other OECD countries.

Informal employment is a significant labour-market problem for a number of reasons (see e.g. OECD (2008b) and Andrews et al. (2011b) for a more detailed treatment). People working in the shadow economy have typically limited social protection and tend to face a high level of income insecurity; they are therefore more exposed to poverty risks. The shadow economy represents a shortfall in terms of tax revenues, limiting the quality of public services and putting greater tax pressure on the formal sector. It therefore induces distortions, as informal firms benefit from unfair competition advantages.

Under-declaration of income is widespread in Poland (although tax compliance has improved), and a large number of employees working in small firms do not have a written employment contract (OECD, 2008b). Informal employment seems to be triggered by the lack of job opportunities in the formal sector, but also by the potential for greater disposable income (Mroz, 2010; Walewski, 2011), owing to the avoidance of income tax and social security contributions, and the existence of unconditional provision of social assistance and the favourable treatment of the self-employed.

Policies and institutions can shape the incidence and scope of informal employment, and the authorities could act in the following dimensions to curb its costs. First, tax regulations should be simplified, as the complexity of the Polish tax system is regularly identified as a major obstacle to conducting business (OECD, 2010a; World Bank, 2013; World Economic Forum, 2013). Complex tax systems increase compliance costs, create opportunities for exploiting loopholes and increase collection and monitoring costs. Moreover, the monitoring and enforcement of the tax system should be enhanced to limit tax avoidance and evasion: unsurprisingly, the incidence of informality seems to be higher in countries where the expected penalty for not declaring earned income to the tax or social security authorities is less severe (OECD, 2008b). Even compared with other Central and Eastern European Countries, audit staffing and activity is underdeveloped in Poland and coordination between the tax, social security and labour-inspection agencies, which is a key enforcement mechanism, is insufficient (OECD, 2008b). Second, the advantages granted to the self-employed should be reduced, as self-employment facilitates tax avoidance and evasion. On top of the many exemptions and deductions in the personal and corporate income taxes, four different preferential tax and social contribution regimes exist for the self-employed, which are likely to favour gaming and abuse (OECD, 2008b). Third, significant barriers to market entry and costly administrative procedures (Égert and Goujard, 2014) need to be removed, as they encourage unregistered work and under-declaration of income (Figure 6, Panel A).

Fourth, unemployment contributions should be reduced and part of the spending they currently finance funded from other sources. Indeed, unemployment benefits (UB) are very loosely related to contributions (see below), which does not encourage formal employment. Moreover, UB spending represents only about one quarter of contributions due to their low level and strict access conditions, and because contributions are also used to fund active labour market programmes and early-retirement schemes. Fifth, as already mentioned, the KRUS should be reformed, as it induces people to hold onto small plots of land even when not being active in farming, thereby encouraging underground employment. 
Finally, the rule of law should be strengthened. Andrews et al. (2011b) highlight a significant cross-country correlation between the size of the informal sector and the effectiveness of institutions securing property rights, establishing an impartial judiciary and limiting corruption (Figure 6, Panels B and C). Also, hours in undeclared work tend to be higher in countries where there is a perception that few citizens play fair, a proxy for the degree of trust between citizens and public authorities (Panel D). Improving government effectiveness and fighting corruption by improving trust in government can raise the willingness to pay taxes and more generally play an important role in reducing informality.

Figure 6. The informal economy
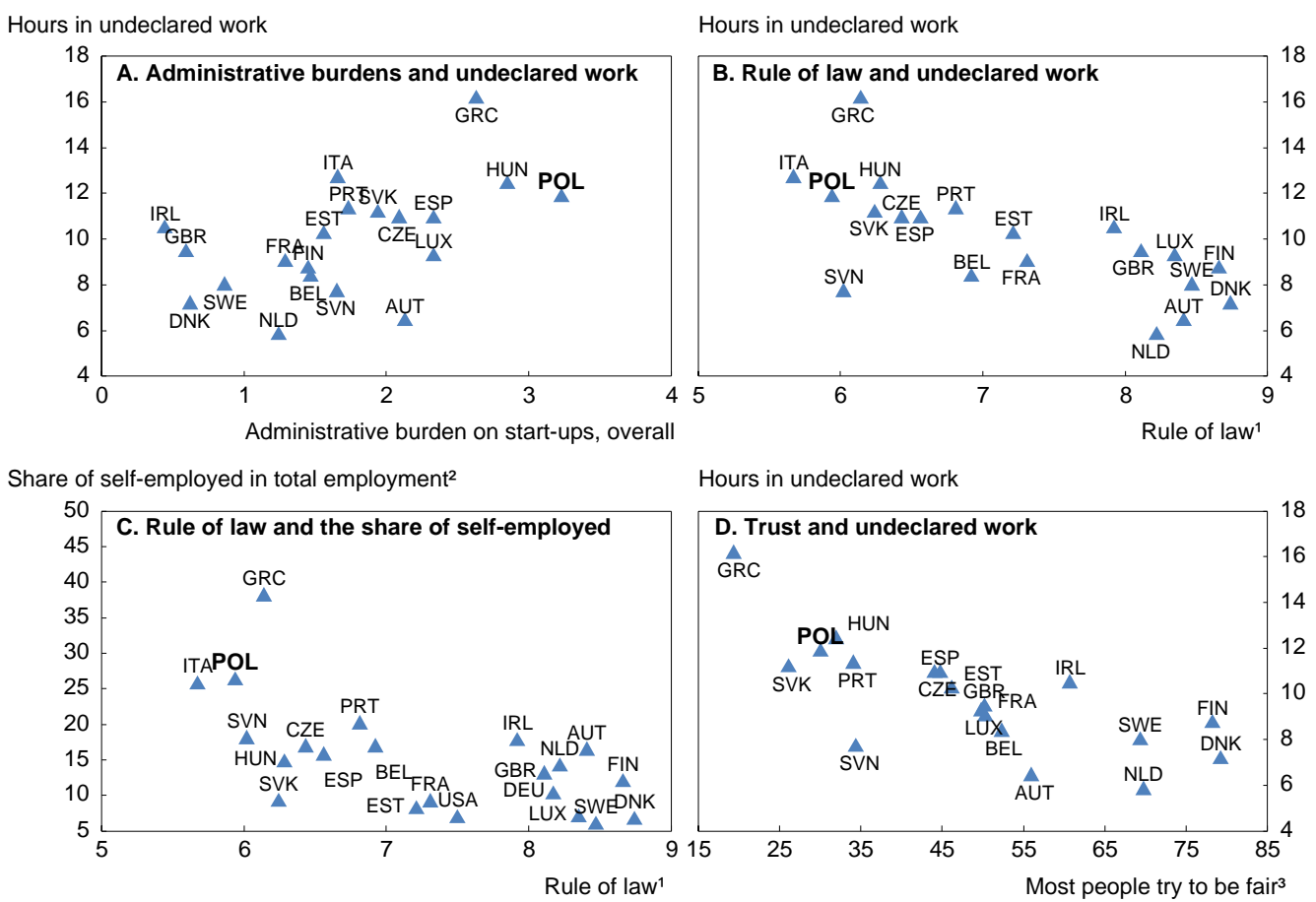

Hours in undeclared work

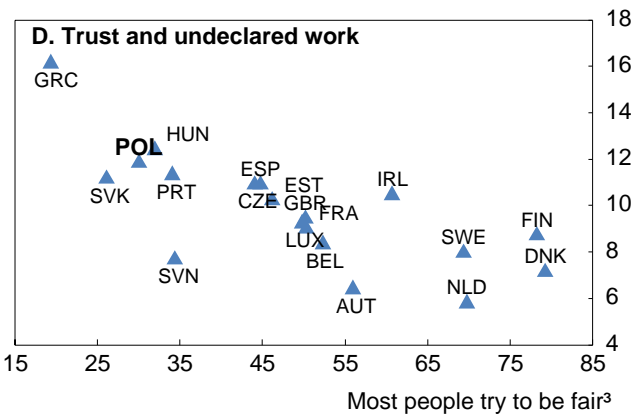

1. Rule of law refers to Area 2 (Legal Structure and Security of Property Rights) of the Economic Freedom of the World Index. This index is based on seven components: judicial independence, impartial courts, protection of property rights, military interference in rule of law and the political process, integrity of the legal system, legal enforcement of contracts and regulatory restrictions on the sale of real property.

2. Average for the period from 1995 to the most recent observation.

3. The horizontal axis shows the proportion of respondents who answered they expect that most people try to be fair.

Source: Andrews et al. (2011b), "Towards a better understanding of the informal economy", OECD Economics Department Working Papers, No. 873.

\section{Labour-market policies to improve overall employment}

\section{Employment protection is deeply segmented}

Employment protection legislation (EPL) is an important determinant of labour market outcomes. Poland is close to average in terms of EPL stringency for permanent contracts (Figure 7, Panel A). In case of dismissal, the union representative must be notified, the maximum length of the notice period is average and severance pay low. Regulation related to the definition of unfair dismissal is also one of the least constraining among OECD countries (OECD, 2013b), but legal procedures in case of disputed separation are long and their outcomes highly unpredictable. Re-employment obligations in case of unfair dismissals are heavy, although reinstatement is not often imposed by the court. The ceiling of three months on 
trial-period contracts, which can be used before an open-ended or fixed-term contract is offered, is one of the shortest, potentially limiting both hiring and the quality of matching (Panel B).

Figure 7. Employment protection, 2013

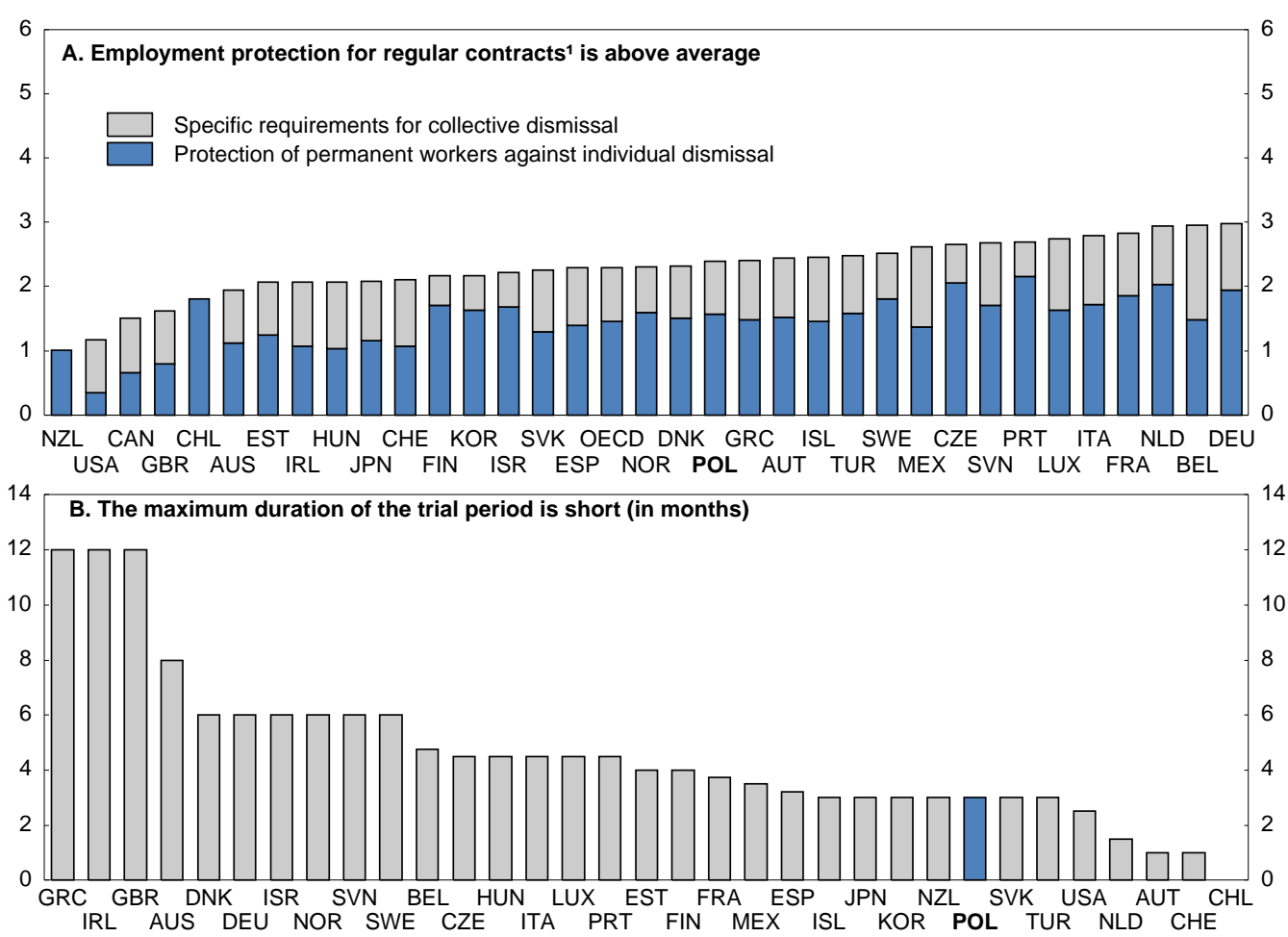

1. Index scale of 0 to 6 , from least to most restrictive; the indicators are displayed in their weighted version.

Source: OECD, Employment Protection Legislation Indicators database.

The labour market is heavily segmented and in a rather complex way. The share of temporary employment in total dependent employment is above $25 \%$, a level exceeded only in Chile (Figure 8 , Panel A). Regulations pertaining to fixed-term contracts (FTCs) have been lax since the reforms conducted between 2001 and 2003. In particular, since the end of 2011, there has been no duration limit either for a given FTC nor for their maximum cumulative duration. These soft provisions have fuelled a sharp increase in the incidence of temporary contracts from about $10 \%$ of total dependent employment in 2001 to more than $25 \%$ since 2005. After numerous changes since the end of the 1990s, a third consecutive FTC now triggers an automatic conversion into an open-ended contract, provided there has not been a break of more than one month - which is rather short - between them.

The reasons why FTCs are so widely used are not totally clear. Prima facie, the strictness of regular employment regulations does not provide a convincing explanation (Panel B). Rather, persistently high structural unemployment is likely to have contributed to this phenomenon by weakening workers' bargaining power and prompting them to accept offers for relatively precarious jobs. 
Figure 8 . The labour market is heavily segmented, $\mathbf{2 0 1 2}^{1}$
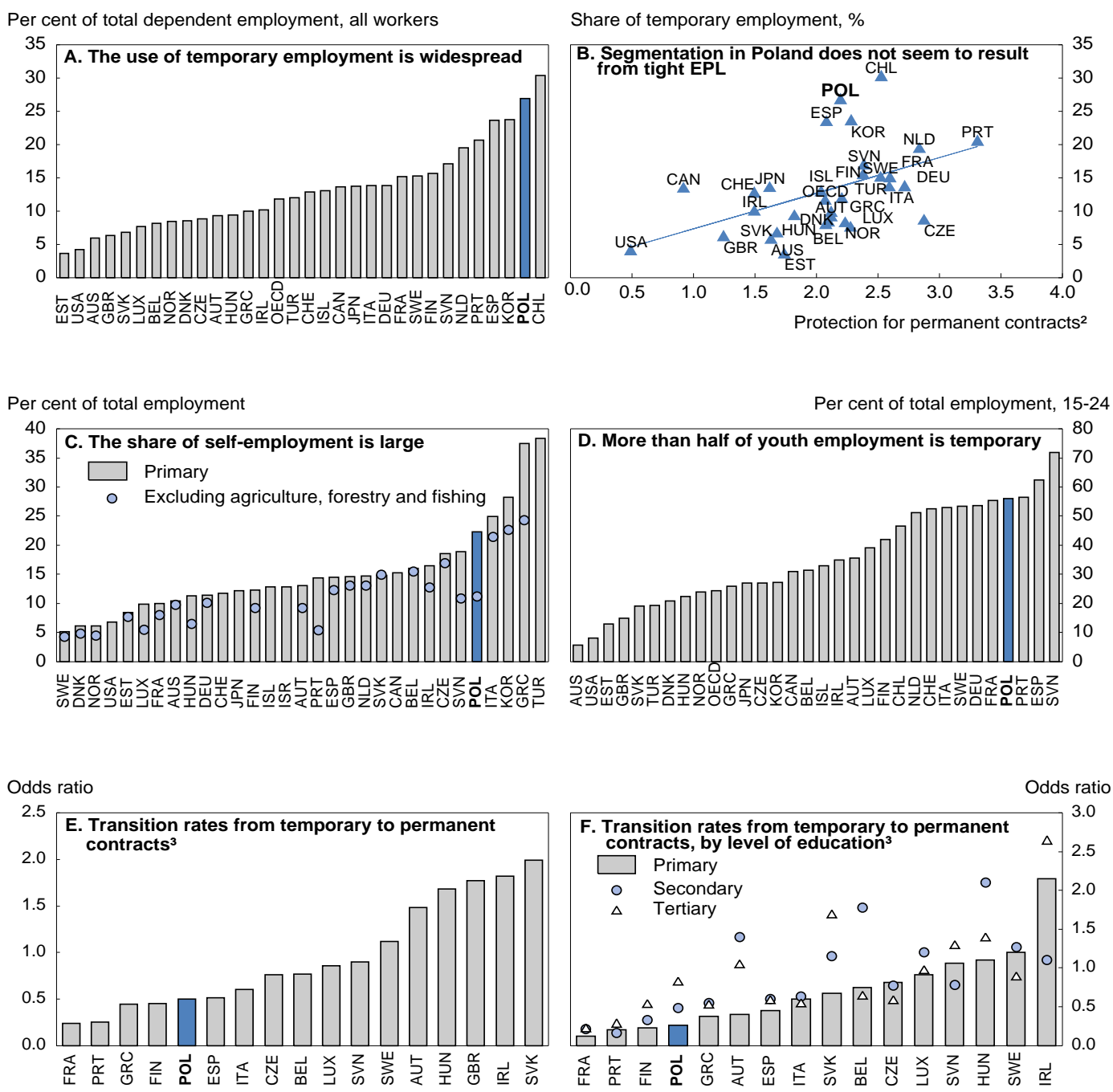

1. For Panels A, C and D: 2011 for Korea; 2009 for Sweden and 2005 for the United States (limitedly to the temporary employment series for the latter).

2. Against individual dismissal.

3. Odds ratio moving to permanent vs. remaining in temporary contract; average 2005-07.

Source: OECD, Labour Force Statistics database and OECD Economic Outlook 94 database; Eurostat (2010), Employment in Europe 2010 (for Panels D and E).

In addition, $22 \%$ of the employed population is self-employed, which is also one of the highest in the OECD, although it has fallen since the mid-1990s when it stood at 30\% (Figure 8, Panel C). Self-employment was boosted by restructuring policies during the transition period, but the extensive use of this form of work reflects both the high share of individual farmers as well as the desire to avoid social-security costs and termination requirements (Trappmann, 2011). Indeed, on top of permanent and temporary contracts governed by the Labour Code, employment relations can take the form of a contract lightly regulated under civil-law provisions. Civil-law employment is less costly for employers and can be more rewarding in the short term for the "self-employed" employees, as it is subject to limited social-protection requirements, including social security contributions. It also escapes minimum-wage regulations. There has been a tendency by employers to "convince" employees to conduct the same work 
as self-employed providers under civil-law contracts (Zientara, 2008), which infringes the Labour Code and could theoretically trigger sanctions by labour inspectors. Kwiatkiewicz (2008) refers to "bogus" self-employment. According to her definition, a self-employed person is someone who provides services for his/her client(s) through a commercial contract, while self-employment is bogus if the relation is de facto one of subordination (dependent employment). These contracts (called "trash contracts" in Poland) represented $30 \%$ of total self-employment (i.e. about $7 \%$ of total employment) in 2012. Among non-agricultural workers declaring revenues from only one source, about $11 \%$ are civil-law contractors. The government plans to subject all civil-law contracts to social security contributions up to a salary equivalent to the full-time minimum wage. This would be a first step in the right direction.

While greater labour market flexibility might have fuelled employment growth between 2003 and 2007 (Ingham and Ingham, 2011), such profound dualism has its flip side and is likely to weigh heavily on other aspects of economic performance. The extensive use of temporary contracts might be detrimental to investment in human-capital formation by both employers and employees. Temporary employment is especially widespread for young workers (Figure 8, Panel D), and such a high incidence seems to lengthen school-to-stable-work pathways and make them more erratic (OECD, 2009). Fixed-term contracts seem to serve more as a screening device than a stepping stone to an open-ended job (Baranowska et al. (2011); Panels E and F). More generally, labour-market dualism might make some specific groups, in particular the young and low-skilled workers, bear a disproportionate part of the costs of adjustment to economic shocks. It might also induce in-work poverty, which is prevalent in Poland (European Commission, 2012b). Raising social contributions for FTCs and lowering them for permanent contracts (such that total labour taxes remain constant) would allow internalising some of the social costs induced by the disproportionate use of FTCs, while neutralising the total impact on the labour tax wedge.

One form of temporary employment, temporary work agency (TWA) employment, faces important restrictions, which should be eased: it is allowed only for tasks whose timely performance by the company's permanent staff would be impossible. TWA workers can perform only seasonal work, ad hoc assignments, tasks that cannot be completed on time by the company's regular workers, and as replacements for a company's long-term absent employees (OECD, 2013c); setting up a TWA requires special administrative authorisation and entails periodic reporting obligations; and TWA employees cannot be treated less favourably than regular employees, including in terms of remuneration (OECD, 2013b). Consequently, and given FTCs' flexibility, TWA employment is not well developed, covering less than 2\% of total employment (Trappmann, 2011).

Finally, until recently, rules concerning maximum working hours were relatively stringent. Basic working time is limited to an average of 40 hours over a five-day working week within a reference three-month period. An employee working overtime is entitled to a top-up of $50 \%$ (or $100 \%$ depending on the time and day). In exchange for overtime work, it is possible to grant compensatory time off to the employee. Work on Sundays and public holidays is restricted. The September 2013 law permanently amending the "Working Time" Chapter of the Labour Code increases working-time flexibility, thereby allowing firms to better cope with fluctuations in demand. The main change refers to the extension from three to 12 months of the reference period used to compute working-time limits, conditional on an agreement involving unions or employees' representatives at the branch or company level.

\section{Alleviating the wage distortions affecting labour utilisation}

Since 2002, wage increases have not matched the pace of labour productivity gains in any year except in 2008, thereby improving cost competitiveness (Figure 3). Thus, the labour share of national income has fallen steadily, leading to one of the lowest levels in the OECD (although level comparisons should be interpreted carefully) (Figure 9, Panel A). High unemployment, greater trade openness, privatisation and the free-fall in unionisation from 36\% in 1990 to $15 \%$ in 2010 have lowered unions' bargaining power and 
might explain why workers have not reaped the full gains from faster economic growth. Moreover, economic inequalities have increased substantially since the end of the 1990s across a broad array of inequality measures (Brzezinski and Kostro, 2010), although Poland is one of the few OECD countries to have recorded a reduction in market-income inequality since 2007 (Panel B).

Figure 9. Labour share and income inequality
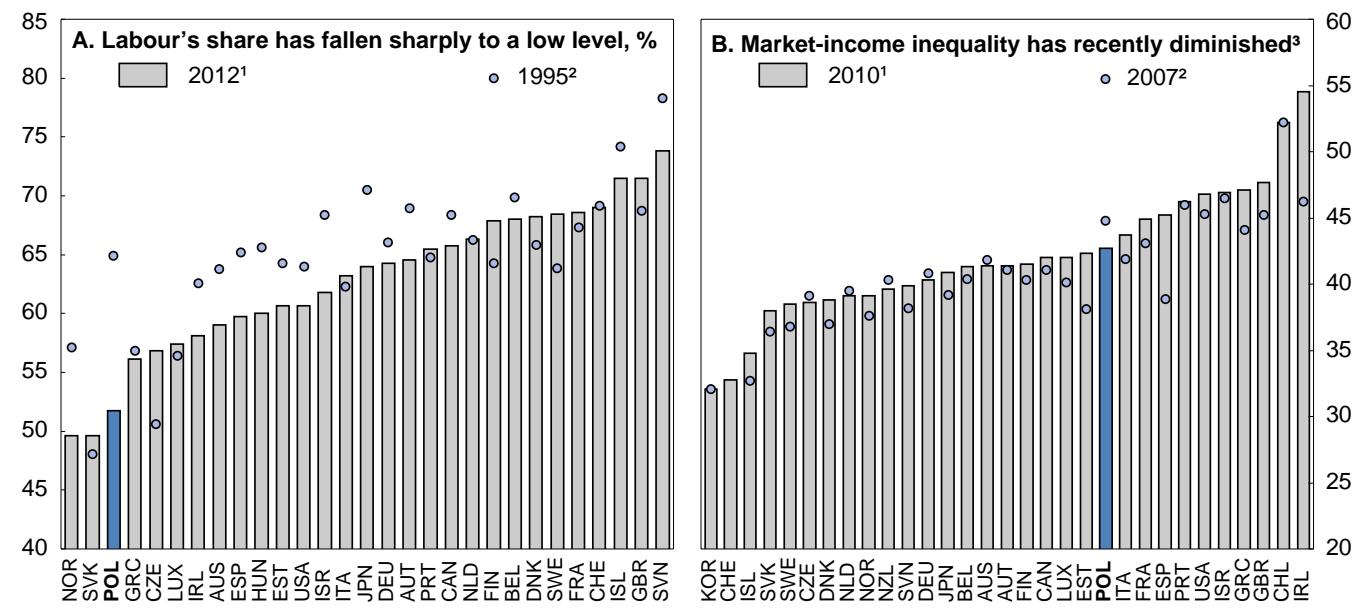

1. Or latest year available.

2. Or closest year available.

3. Gini index before taxes and transfers, working-age population.

Source: OECD Economic Outlook 94, OECD Income Distribution and Poverty databases.

The wage distribution is much more compressed in the public than in the private sector, even when controlling for educational attainment. The private sector offers higher wages on average to the most qualified workers, while the public sector pays relatively higher wages for the low-skilled (Ministry of Labour and Social Policy, 2008). For example, monthly earnings of cleaners working in the public administration are on average more than $40 \%$ higher than in the industrial sector. Caretakers, janitors and porters earn about $15 \%, 30 \%$ and $60 \%$ more, respectively, in public administration. On average, despite the restraint imposed on the public-sector wage bill since 2009, the average compensation rate of public employees remains high in relative terms at about $150 \%$ of the average private-sector compensation compared with $100 \%$ at the end of the 1990 s. Moreover, pay tends to increase faster with seniority in the public sector, reflecting more rigid compensation schemes that might not reflect individual productivity. These features are likely to generate inefficiencies in the allocation of labour resources.

Private-sector coverage by collective agreements is relatively low at about $40 \%$ compared with an OECD average of $53 \%$, and wage bargaining is to a large extent decentralised to the firm level, similar to the situation in Hungary, the United Kingdom and the United States (Du Caju et al., 2008). The main source of private-sector wage rigidities is the minimum wage. It is negotiated first within the Tripartite Commission and then between the Commission and the Council of Ministers, which has the final say. By law, the minimum wage is indexed to inflation, plus at least two-thirds of real GDP growth as long as the minimum-to-mean wage ratio is lower than 50\%. Unions have an explicit target of $50 \%$ for the minimum-to-mean wage ratio, and even though they are relatively weak, except in some occupations such as miners and teachers, they have fairly strong nationwide political power and exert pressure on the government in the minimum-wage-setting process.

On the one hand, the minimum-to-mean wage ratio, equal to $38 \%$ for full-time employees in 2012 , is not high by international standards (Figure 10, Panels A and B). On the other hand, the wage distribution is 
clearly skewed, suggesting that the minimum wage might be an important constraint (Panel C). While the minimum-wage level is unlikely to affect labour demand substantially in the relatively rich Mazowieckie region, for example, it might penalise employment opportunities for youth and the low-skilled in remote high-unemployment areas (Panel D). A uniform minimum wage is at odds with the fact that the productivity of a given individual may vary geographically because of agglomeration effects, amply documented in the economic geography literature (Fujita et al., 1999; Melo et al., 2009). The cost of living also varies greatly across the country, implying large regional differences in the purchasing power of the minimum wage. Therefore, as suggested in past Surveys of Poland (e.g. OECD, 2010a), performance might be improved by decentralising minimum-wage setting to the regional level, especially given persistently low internal mobility. However, given that the heterogeneity of employment performance is also substantial within regions, regionalised minimum wages might help only partially.

Figure 10. Minimum wage
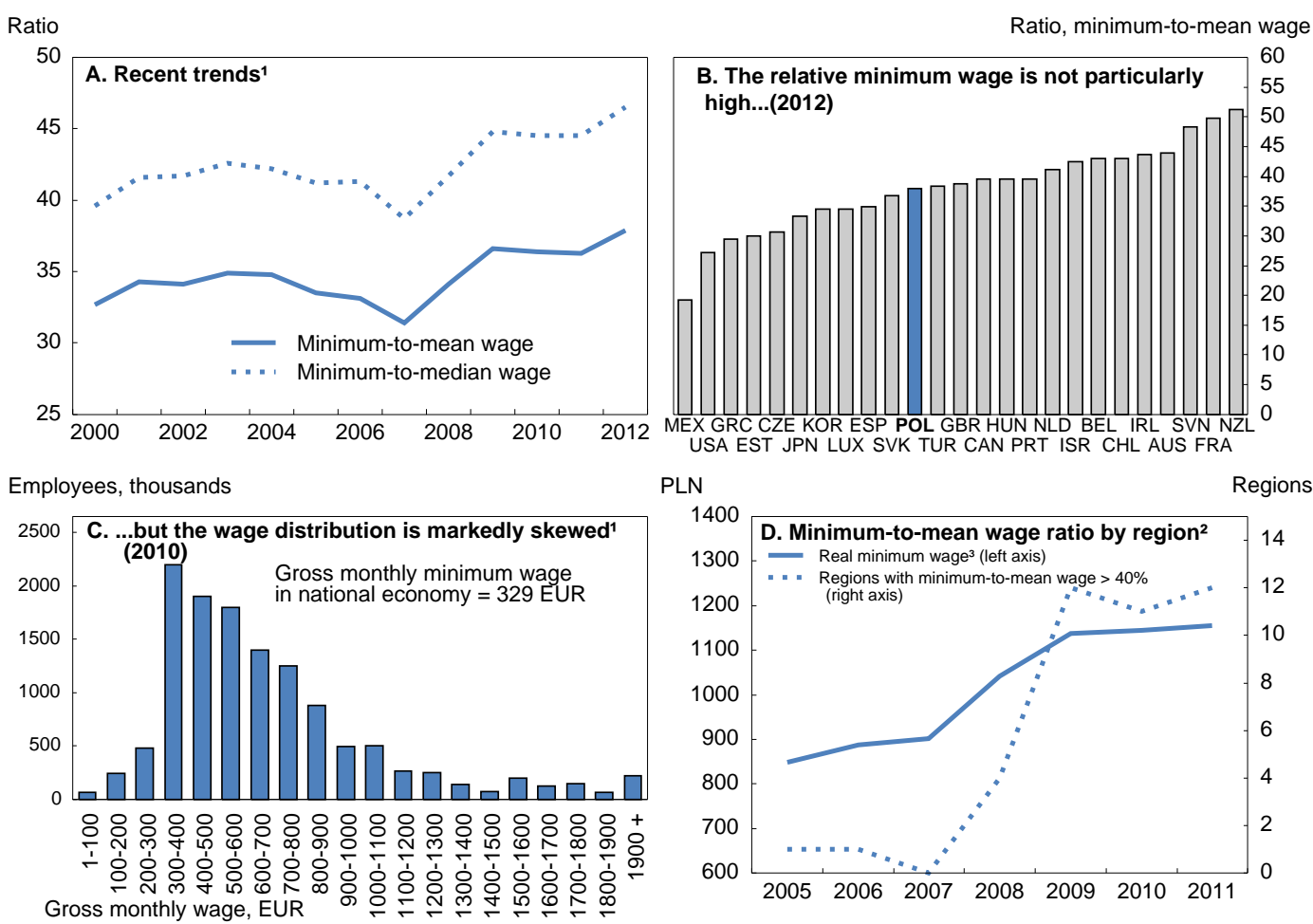

1. Data on the wage distribution should be interpreted with caution, as the underlying survey covers only firms with at least 10 employees.

2. The graph shows the increasing number of regions in which the minimum-to-mean wage ratio exceeds $40 \%$.

3. Deflated by the CPI.

Source: OECD. Minimum wage database; Ministry of Labour.

\section{Better activating the unemployed}

The unemployment benefit system has strict eligibility rules, but some features should be modified

Eligibility for the unemployment benefit (UB) system is strict, and replacement rates are typically low (Figure 11, Panel A). To be eligible, an unemployed person needs to register at the local labour office and have a year's work history during the 18-month period preceding registration and be paid at least the full-time minimum wage, thereby excluding most part-time workers. Overall, in 2012 fewer than $20 \%$ of 
registered unemployed were entitled to UB, much less than in most other OECD countries (Panel B). UB is thus unlikely to reduce employment incentives substantially, except potentially for specific groups (see below). The benefit is a flat-rate payment, i.e. unrelated to past individual wages and contributions, which are equal to $2.45 \%$ of gross wages. In 2012 , UB amounted to slightly more than half the minimum wage for the first three months and is diminished by $20 \%$ after that. The benefit is reduced (increased) by $20 \%$ for those having less than five (more than 20) years of work experience. For those who were paid close to or above the average wage, this implies very low replacement rates. The entitlement period lasts six months, but it is extended to 12 months in three cases: in districts where the unemployment rate exceeds $150 \%$ of the national rate; if the unemployed person is over 50 with at least 20 years of work experience; or if $\mathrm{s} /$ he supports a child under 15 and the spouse is also unemployed but no longer eligible for UB.

Figure 11. Unemployment benefit is not generous
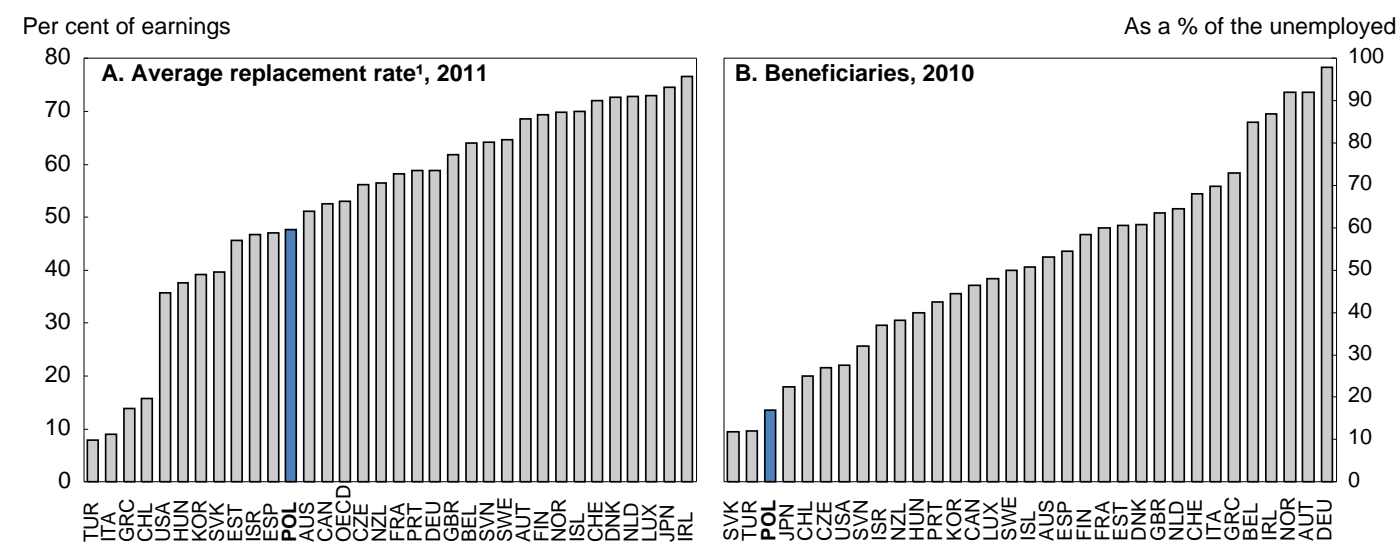

1. Average of the net replacement rate in the first five years of unemployment for four different family types (single and one-earner couples, with and without children) and two earning levels (67\% and $100 \%$ of average full-time wages). Unemployment benefits plus cash social assistance.

Source: OECD, Benefits and Wages database; ILO.

The longer UB eligibility for senior workers and in districts with higher unemployment may reduce labour supply, especially given the uniformity of the minimum wage level. Based on international evidence (RWI, 2005), geographically differentiating the length of the UB period discourages internal migration from high-unemployment areas. However, there is no specific study focusing on Poland and, given the low level of UB, these possible disincentive effects are likely to be small.

There are strong incentives to register as unemployed despite meagre UB, even if one is not looking for work. While the principle of universal health-care coverage is enshrined in the constitution, the unemployed need to register at the local labour office in order to get health-care coverage for themselves and their families. Registering also allows easier access to social assistance. This creates a situation where some people not searching for a job and not wanting to work (or might even be working informally) register just to get the insurance. More than $25 \%$ of the registered unemployed might be in that situation, according to the Ministry of Labour (PNB, 2013). This feature explains a large proportion of the 3 percentage-point gap between the LFS and the registered unemployment rates. It also implies that some job-search support is bound to fail (because some registered unemployed do not want to find a job), thus discouraging both public employment service (PES) staff and employers posting job offers. Therefore, disconnecting entitlement to health insurance from unemployment registration would help.

The unemployed are theoretically required to accept any suitable job offer - defined as one for which daily commuting time would not exceed three hours - and cannot restrict job search to the occupational field or level of his/her professional qualifications. However, in practice the PES does not refer the 
unemployed to jobs for which they are distinctly over-qualified. Moreover, monitoring of job-search activity is minimal. While the unemployed must be ready to take up full-time employment and the sanctions in the case of refusal of employment or participation in ALMPs are relatively severe, there are generally no formal job-search requirements apart from being registered as unemployed, reporting to the labour office at designated dates to confirm availability and receive information on employment and training opportunities, and accepting job offers, training or other forms of support (Venn, 2012). OECD Surveys of Poland (e.g. OECD, 2008a) have previously recommended tightening work-availability and job-search requirements, which would also help fighting informal employment, but there has been no follow-up action.

\section{Making work pay}

Housing benefits, family benefits and other social assistance (apart from KRUS and old-age, disability and survivors' pensions, which are discussed elsewhere in this paper) are relatively well targeted. As discussed above, the replacement rates for unemployment benefits alone are low, especially for those with previously high earnings. However, when unemployment benefits are combined with other transfers, situations arise where replacement rates become very high. This is the case for low-wage earners, and especially so for lone parents (Figure 12). This nexus can therefore produce strong disincentives to take a job.

Figure 12. Overall net replacement rates are high only for those on low wages

Families qualifying for social assistance ${ }^{2}, 2011$
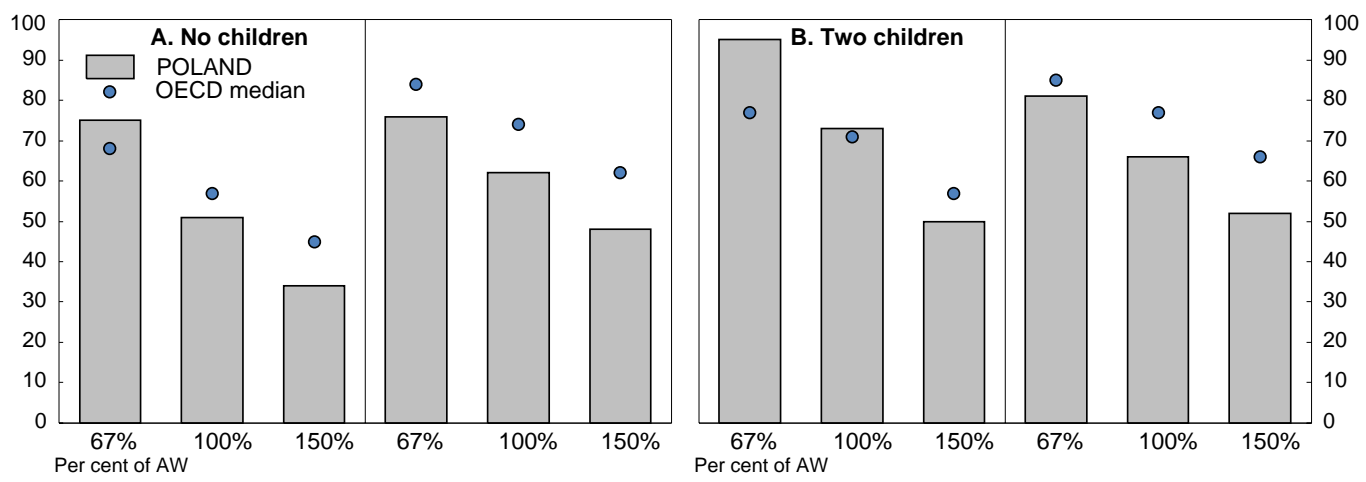

Single person

Two-earner married couple

Lone parent

Two-earner married couple

1. Initial phase of unemployment but following any waiting period. Any income taxes payable on benefits are determined in relation to annualised benefit values, even if the maximum benefit duration is shorter than 12 months. For married couples the percentage of average wages AW) relates to the previous earnings of the unemployed spouse only; the other is assumed to have full-time earnings equal to $67 \%$ of $\mathrm{AW}$ in a two-earner couple. Where receipt of social assistance or other minimum-income benefits is subject to activity tests (such as active job-search or being available for work), these requirements are assumed to be met. Children are aged four and six, and neither childcare benefits nor childcare costs are considered.

2. After tax and including unemployment and family benefits. Social assistance and other means-tested benefits are assumed to be available subject to relevant income conditions. Housing costs are assumed equal to $20 \%$ of AW.

Source: OECD Tax-Benefit Models.

The labour tax wedge has been reduced (through lower personal income tax in 2009) toward the OECD average level, though the increase in disability contributions from $6 \%$ back to $8 \%$ in 2012 (after $13 \%$ in 2007) worked the other way. More precisely, the average tax wedge is slightly above the OECD average, while the marginal tax wedge is slightly below it (Figure 13). Yet, given that labour taxes are among the least progressive in the OECD, such tax-wedge levels tend to apply also to low wages, thus penalising low-skilled employment significantly, especially in regions where the minimum wage acts as a 
binding constraint. Overall, making some social-assistance benefits (such as childcare subsidies) conditional on working or on seeking work and introducing a targeted earned-income tax credit would improve work incentives.

Figure 13 . The average tax wedge is slightly above OECD average, while the marginal tax wedge is lower, ${ }^{1} 2011$
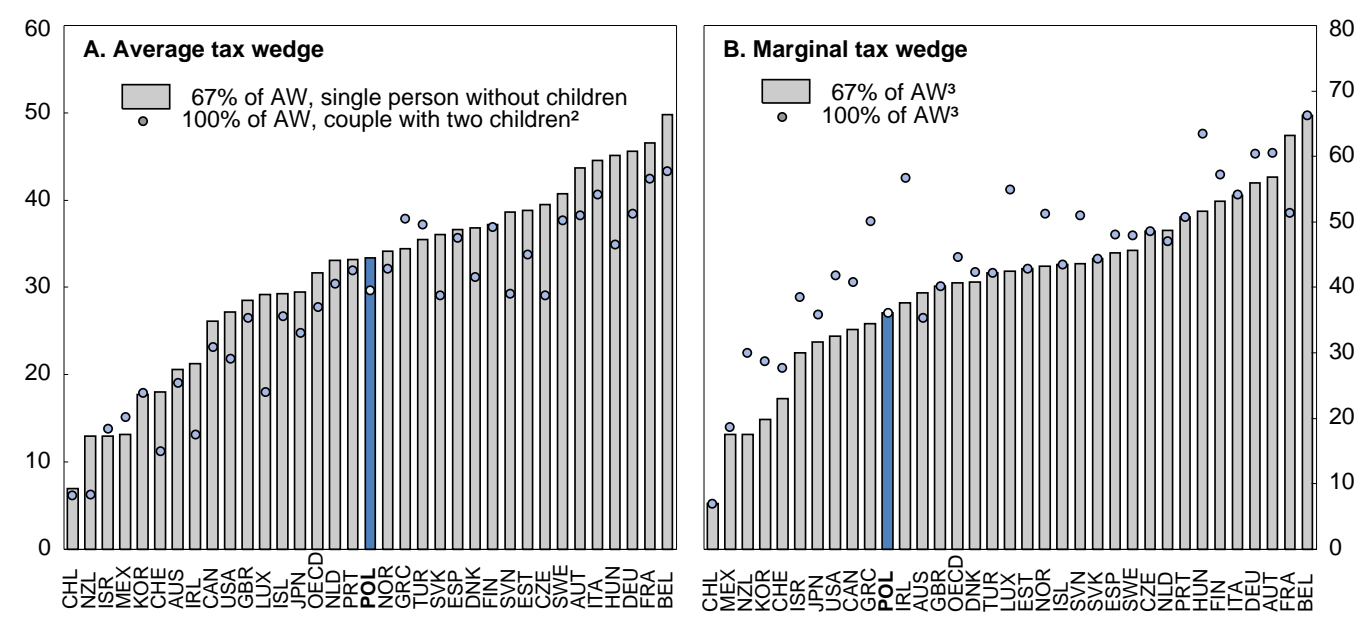

1. The average tax wedge is measured as the difference between total compensation paid by the employer and net take-home pay, as a ratio of total labour compensation. It includes both employer and employee social contributions. The marginal wedge is measured as the difference between the changes in total labour compensation paid and in net take-home pay, as a result of an extra unit of labour income. The difference is expressed as a percentage of the change in total labour compensation.

2. Couple with two children, at $100 \%$ of average worker earnings for the first earner. Average of three situations regarding the wage of the second earner $(0 \%, 33 \%$ and $67 \%$ of average worker earnings).

3. Single person without children.

Source: OECD (2012), Taxing Wages database.

\section{Enhancing the functioning of public employment services and improving active labour market policies}

The public employment service (PES) system is at least in principle largely decentralised. It is run by 340 labour offices operated by the 16 regional and 380 district administrations. The Ministry of Labour and Social Policy sets regulations and co-ordinates the PES across the different actors, but labour offices are autonomous and define programmes in their geographical area. About $80 \%$ of PES resources come from the Labour Fund, which is managed by the Ministry and financed by unemployment contributions and to a small degree (about 6\%) by EU funds, with the remainder from local governments. The Ministry allocates the Labour Fund's resources to the regions depending on various local unemployment data, and each region in turn allocates resources to the labour offices, which determine detailed eligibility criteria and manage benefit payments.

There is a broad consensus that the PES works poorly in Poland (Kaluzna, 2009). First, it lacks resources, suffering in particular from under-staffing. Although the situation has improved, workload indicators still paint a bleak picture. In 2012, each placement officer supervised as many as 595 registered unemployed on average (against 1132 in 2006 and 1637 in 2000). Second, although insufficient, available staff resources are not used efficiently: a vast number of them work on back-office administration tasks and even those in the front-line placement functions are burdened by excessive bureaucracy (Kaluzna, 2009). In addition, high staff turnover, driven by unattractive compensation and by the instability of labour market programmes, generates heavy losses in human capital at PES offices. Third, most staff seem to lack the skills required to achieve a good level of job-search support (Grotkowska and Sztanderska, 2008; Trappmann, 2011), in part due to cronyism in the recruitment process (OECD, 2009). The situation might have improved recently, however, given the increase in the share of employees with a 
higher education level. Nonetheless, local governments' labour offices and social assistance centres seem to have a poor understanding of the overall labour market situation, in part due to the lack of relevant information and their staffs' inadequate analytical skills (Kaluzna, 2009). This is unfortunate, as international evidence suggests that a high standard for PES staff is a crucial ingredient for efficient activation.

As a result, monitoring of job-search efforts is weak (Venn, 2012), and occupational counselling and job-placement services suffer from a poor reputation in the minds of both employers and job-seekers (Trappmann, 2011). Only about half of all firms contact local labour offices when they want to recruit, resulting in high matching costs. There also seem to be large and growing differences in services provision across labour offices. While this might be related to the decentralised organisation of PES functions in a way that does not necessarily reflect inefficiencies, lack of coordination and of automatic exchange of information might also induce persistent and symptomatic heterogeneity in service quality.

PES quality is also affected by serious coordination problems. Grotkowska and Sztanderska (2008) highlight the need for better coordination of PES with firms, the municipalities, especially their social assistance centres, and education institutions, including those involved in professional education. When sanctions are applied to the unemployed, they are often revoked by the Ministry, weakening the authority of labour offices. There is also poor coordination between the PES and the Social Security Institution (ZUS) when job offers are refused for medical reasons. Kaluzna (2009) reports that when labour offices ask for further verification of "strange" medical statements, the ZUS usually refuses, arguing that the unemployed do not fall under their competence.

In recent years the budget allocated to labour market policies has amounted to about $0.6-0.9 \%$ of GDP, well below the OECD average of about 1.5\% (Figure 14). When expenditures are computed per LFS unemployed and expressed as a percentage of GDP per capita, Poland has a low ratio of $16 \%$. That ratio increased until 2010 due to the expansion of resources dedicated to ALMPs in a context of falling unemployment, but ALMP spending was cut after that to cope with overall fiscal tightening. Notwithstanding the question of their efficiency, the pro-cyclicality of ALMPs is unfortunate.

Figure 14. Public expenditures on labour market policies are on the low side, $2011^{1}$

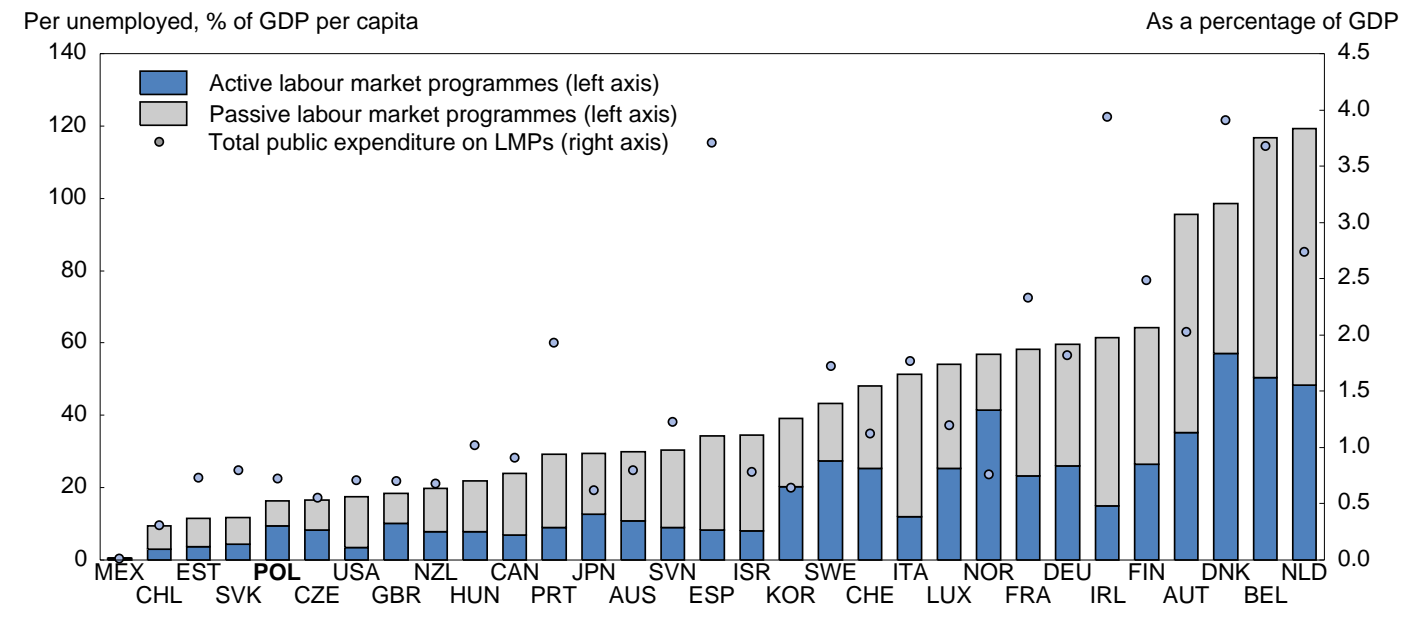

1. 2010 for Ireland; 2009 for the United Kingdom and 2007 for Norway.

Source: OECD, Labour Market Programmes statistics.

Table 1 provides a breakdown of labour market expenditures in Poland since 2007. Over the past few years passive labour market policies have amounted to about $0.4 \%$ of GDP, two thirds in the form of 
unemployment benefits and one third of pre-retirement schemes covering about $1 \%$ of the labour force in 2012, down from about $3 \%$ in 2002. ALMPs consist mainly of: training; subsidised employment targeted at centrally defined disadvantaged groups (so-called "intervention works" in the private sector, and "public works" and "socially useful works" in the public sector and non-governmental organisations); start-up subsidies; and the unusual item "doctors' specialisation courses and internships".

Table 1. Expenditure on labour market policies

PLN millions

\begin{tabular}{|c|c|c|c|c|c|c|}
\hline & 2007 & 2008 & 2009 & 2010 & 2011 & 2012 \\
\hline Total expenditure & 5353 & 5756 & 11245 & 12234 & 8744 & 9351 \\
\hline Per cent of GDP & 0.46 & 0.45 & 0.84 & 0.86 & 0.57 & 0.59 \\
\hline Unemployment benefits (including SSC) & 2207 & 1833 & 2851 & 3274 & 3047 & 3403 \\
\hline Pre-retirement benefits and allowances ${ }^{1}$ & 0.4 & 0.1 & 1555 & 1618 & 1625 & 1788 \\
\hline ALMPs & 2725 & 3363 & 6205 & 6627 & 3340 & 3875 \\
\hline Training & 27 & 279 & 377 & 897 & 134 & 184 \\
\hline Intervention works & 213 & 195 & 179 & 215 & 185 & 139 \\
\hline Public works & 178 & 249 & 330 & 477 & 155 & 165 \\
\hline Apprenticeships & 691 & 917 & 1350 & 1466 & 836 & 855 \\
\hline Vocational training & 379 & 535 & 323 & 242 & 299 & 226 \\
\hline Co-financing of costs to employers of training of adolescents & - & - & 254 & 331 & 290 & 303 \\
\hline Refunding cost of workplace equipment & 365 & 385 & 514 & 807 & 181 & 381 \\
\hline Grants for starting a business & 536 & 701 & 1092 & 1387 & 442 & 708 \\
\hline Doctors' specialisation courses and internships & - & - & 568 & 670 & 718 & 755 \\
\hline Other & 421 & 560 & 634 & 715 & 732 & 285 \\
\hline
\end{tabular}

1. In 2004-08 the financing of pre-retirement allowances and benefits was made from the state budget by the Social Insurance Institution. Since the beginning of 2009, responsibility for this expenditure returned to the Labour Fund. Pre-retirement schemes include pre-retirement benefits and allowances, which are granted to the unemployed under certain conditions of work experience (25-30 years for women, 30-35 for men) or age (55-56 years for women, 60-61 for men) to bridge the gap to retirement.

2. This apprenticeship programme differs from those developed within the Vocational Education and Training system. It refers to specific contracts not exceeding 12 months, supervised by local labour offices and paid $120 \%$ of the standard UB level.

Source: Ministry of Labour and Social Policy.

In countries where the UB system is generous, efficient ALMPs could be useful to counteract its work-disincentive effects. However, Poland has both low UB generosity and a low level of ALMP spending, as have English-speaking countries which achieve high employment rates. Australia is a case where ALMP spending is low but very efficient (OECD, 2012b). In sum, while higher ALMP spending might have some merit in Poland to reduce the mismatch between workers' skills and labour market needs, improving their efficiency is the priority, especially in a tight budgetary environment.

Job-search assistance and career guidance should remain the first line of attack, especially for those unemployed who are job-ready (OECD, 2013d). While education and training programmes might have low returns, in a downturn they can prepare the long-term unemployed to take advantage of new job opportunities once the labour market improves. Also, subsidies to non-profit employment may provide a rapid countercyclical response, but they generally do not have a lasting impact on the school-to-work transition (Box 4.1 in OECD, 2008c). In addition, combining work with a significant training promotes labour market integration, especially for apprenticeship (OECD, 2013d). Finally, start-up subsidies seem to have low efficiency (Dar and Tzannatos, 2009). This evidence suggests that ALMPs in Poland should focus more on improving job-search assistance and apprenticeships.

OECD (2013b) provides additional lessons drawn from in-depth reviews of activation policies in seven OECD countries. First, reforms that have been critical to improve activation strategies have often 
included mergers or co-location of three main services: job broking, referral to active measures and benefit (UB and social assistance) administration. The objective is not only to create a one-stop shop to access all such services, but more fundamentally to integrate their management. In the United Kingdom, merging the PES and the benefit agency seems to have improved service delivery through better coordination and employment outcomes. In Australia, Centrelink is a single entry point for health, social and welfare payments and services. The main advantages of this type of integration are to enhance the coherence of a broad range of social services and facilitate the enforcement of sanctions. In Germany as well, the success of the Hartz IV reform seems to have resulted from better coordination, lower caseloads for PES employees and the development of performance incentives for local employment agencies (Jacobi and Kluve, 2007).

Second, the effectiveness of the PES and any private counterpart can be improved through performance management, as measured in terms of job placement and longer-term outcomes, especially for harder-to-help groups (OECD, 2012b; OECD, 2013b). Australia and Switzerland, which can be used as benchmarks in this area, have designed sophisticated methods to measure performance of local labour offices in terms of gross outcomes (number of action plans completed, registered vacancies filled, job-placement rates, etc.) adjusted using regression results that account for variation in individual job-seeker and local labour-market characteristics. Strengthening the umbrella function of the Ministry of Labour and Social Policy might be worth considering as regards: the development of capacities to evaluate the local PES in order to identify best practices; the effective use of a nationwide information system connecting job vacancies, registered unemployed and ALMPs caseload; and the setting up of standards to deliver key services (profiling, job-search assistance, assignment to ALMPs, sanctions) (OECD, 2009). The government plans to start benchmarking labour offices in 2014. Third, a quasi-market for employment services can operate, as shown by the Australian experience, but it requires an active management framework, which hinges critically upon rewarding the outcomes of providers in order to ensure that only the best performers remain in the market (OECD, 2013b).

Contracting out PES activities has been permitted in Poland since 2004, but there are currently only a few private job agencies. The government plans to contract out only the most difficult cases. Recent action has included the implementation of a pilot project, "Partnership for Jobs", for outsourcing employment services to private agencies in three regions and a draft law introducing the monitoring of ALMPs and rewarding the best performing labour offices (European Commission, 2013). Moreover, the government intends to improve jobseeker profiling, which is crucial to better tailor support to individual needs, especially for those who are the furthest away from employment. Each jobless person would have a personal case officer and be classified as either active, requiring support or remote from the labour market, and assistance would be provided accordingly (PNB, 2013). Activation could also be based on regular in-person reporting of unemployment status. In Australia, job-search requirements involve reporting 8 to 20 job-search actions by the unemployed person every two weeks (OECD, 2013b).

\section{Policies targeted at specific workforce groups}

\section{Boosting female participation}

The female employment rate is low (Figure 15). Even when it is computed relative to its male counterpart, Poland ranks slightly above the OECD average but in the bottom tier of countries, in part due to low participation at older ages. Obstacles to female employment arise from both policies and social norms, which are themselves influenced by policies.

First, old-age pensions are generous for women. The statutory female retirement age of 60 is below its male counterpart of 65 , a feature that persists in only a small and diminishing number of OECD countries (OECD, 2012a). Although the incentives built into the pension system imply only a low implicit tax on 
continued work at older ages (OECD, 2013a), female participation might still be influenced by the legal retirement age of 60, which tends to shape social norms. Following the 2012 reform, the retirement age will be raised to 67 for both genders, phasing in the increase until 2020 for men and 2040 for women. This is welcome, but the pace for women should be accelerated in order to achieve convergence much earlier, for example by 2030. The pension system is all the more generous for women: the gender difference in average life expectancy at 65 was 4.3 years in 2012, well above the OECD average (Figure 16, Panel A), and although the pension is inversely proportional to remaining life expectancy at retirement age, unisex mortality tables are used, thus under-estimating women's true average life expectancy.

Figure 15. Female employment rate is weak, 2012
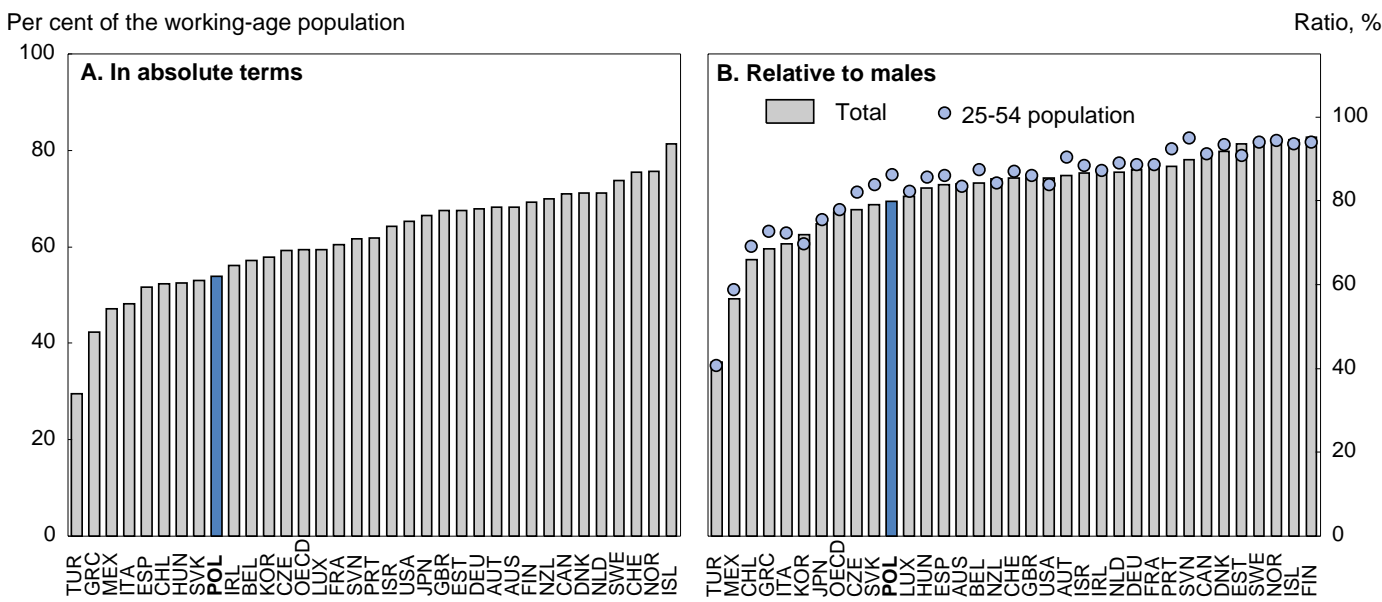

Source: OECD, Labour Force Statistics 2013 database.

Figure 16. The pension system is generous for women
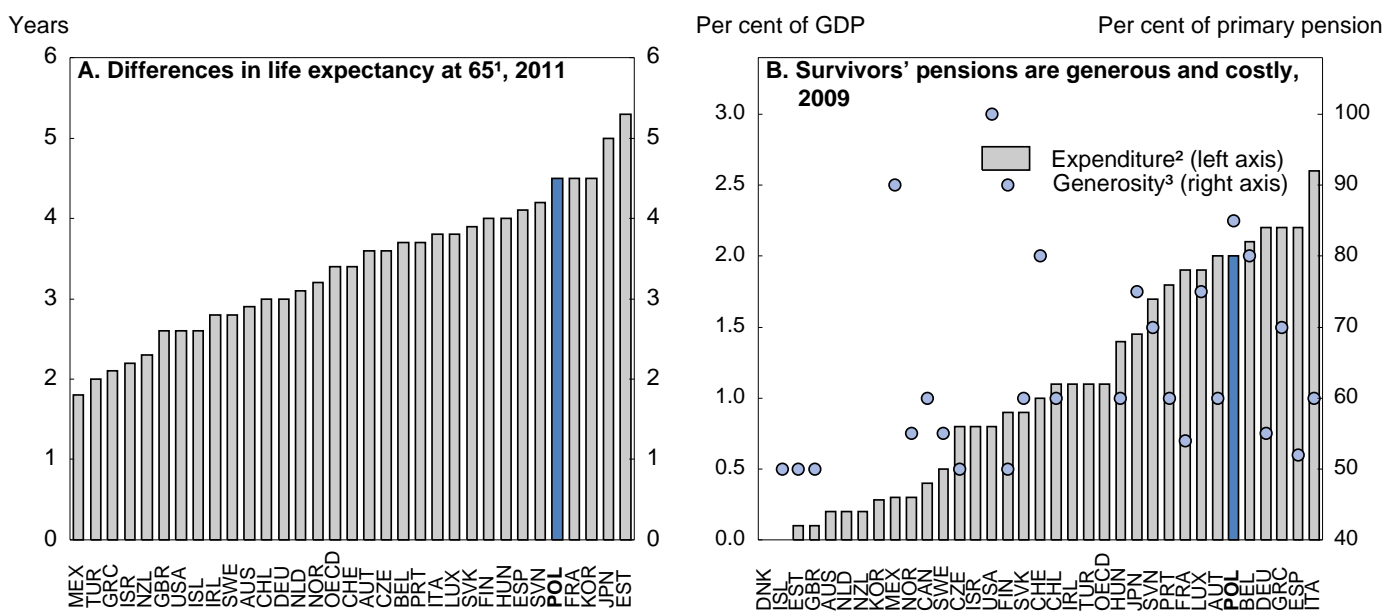

1. Difference between females and males.

2. Public expenditure on survivors' pensions.

3. Survivors' benefits, as a percentage of individuals' primary pension entitlements.

Source: OECD, Social Expenditure (SOCX) database; for Panel B: E.R. Whitehouse. (2013), "Adequacy and sustainability of pension systems: evidence from Europe," mimeo and E. James (2009), "Rethinking Survivor Benefits", World Bank, Social Protection and Labor Discussion Paper, No. 928. 
Second, the survivors' pension regime is expensive and undermines work incentives. Spending on the regime, about $90 \%$ of whose beneficiaries are women (Whitehouse, 2013), is comparatively high as a share of GDP (Figure 16, Panel B). While the primary goal of such pensions is to maintain or protect the survivor's standard of living on bereavement, $85 \%$ of their deceased partner's pension is awarded to the survivor, a proportion which tends to increase the survivor's standard of living substantially and one of the highest in the OECD. In Poland, widow(er)s can receive a survivors' pension already at the age of 45. Moreover, the benefit falls if the survivor has earnings, reducing work incentives. Such a system implies redistribution from women who engage in paid work to those who do not and from singles and dual-career couples to single-earner couples (James, 2009). This is because the amount of the pension does not take into account the cost of this type of life insurance at the individual level. Scaling back this programme and reducing the marginal implicit tax involved would increase employment and reduce the overall tax burden.

Third, the tax system features joint taxation of spouses, which boosts the marginal tax rates for second earners if the income gap between spouses is significant. The narrow base of the personal income tax and its relatively low progressivity limit the negative impact in Poland, though. Nevertheless, the government should consider adopting an individual tax system, as many other OECD countries have done (OECD, 2006a), to encourage labour force participation of women, especially those with low educational attainment.

Fourth, the deeply rooted "traditional" family model exerts social constraints on female labour market participation. Long-term care institutions are underdeveloped in Poland (OECD, 2012a), and elderly care is mostly provided by families - typically spouses and children (mainly daughters) (Golinowska and Sowa, 2010). This difficulty is compounded by the poor availability of flexible working-time arrangements, including part-time work. Young mothers and single parents also have low employment rates in Poland, although they are even lower in other CEECs (Figure 17, Panel A). While childcare costs are relatively modest (OECD, 2011a), the insufficient development of childcare and pre-primary-school institutions (Panel B) is persistently cited as a major structural weakness (see OECD, 2013a). The number of places in nurseries almost doubled between 2010 and 2012, but their total capacity remains extremely low (about 50000 places compared to about 390000 children born annually in Poland). Yet, important progress has been made recently. Pre-school education became compulsory from the age of five in 2011, and primary education will start at age six (rather than seven) in 2014. In June 2013 the government drastically reduced parents' direct costs of accessing kindergarten. According to a July 2013 regulation, every four year-old will have the right to participate in pre-school education from September 2015 and every three year-old from September 2017. The government intends also to develop a variety of child-care arrangements. A July 2013 law extended beyond municipalities the list of institutions (such as non-public entities or private persons) that will be able to apply for funding from the state budget for the establishment and operation costs of childcare institutions for children under three.

Child-related leave is generous. Fully paid maternity leave was increased from 16 to 18 weeks in 2006 and to 26 weeks in 2012, including 6 optional weeks. It was extended by an additional and optional 26 weeks in June 2013 paid at $60 \%$ of salary (Figure 17, Panel C), with fathers being entitled to take unused leave (on top of their fully paid 2 weeks of paternity leave). That additional spending might have been better spent on childcare facilities (European Commission, 2013). On top of this, the parental leave of 36 months (entitled until the child is five years old) is also the longest among OECD countries (Panel D). It includes a means-tested monthly benefit of PLN 400 (EUR 95), which is low although beneficiaries' old-age pension contributions are paid by the State. While excessively short parental leave can reduce employment by inducing young mothers to drop out entirely from the labour force, long periods of leave are likely to weaken their attachment to the labour market, generate a loss of human capital and reduce incentives for employers to invest in female workers (OECD, 2012c). About half of entitled women went on childcare leave in the mid-2000s, but the scheme was even more used by mothers with a low level of education, given the low benefit level and means-testing (BERR, 2012). According to BERR (2012), the 
high level of take-up is due to underdeveloped childcare services, limited availability of part-time work and inflexible work arrangements.

Figure 17. Family policies are detrimental to female employment
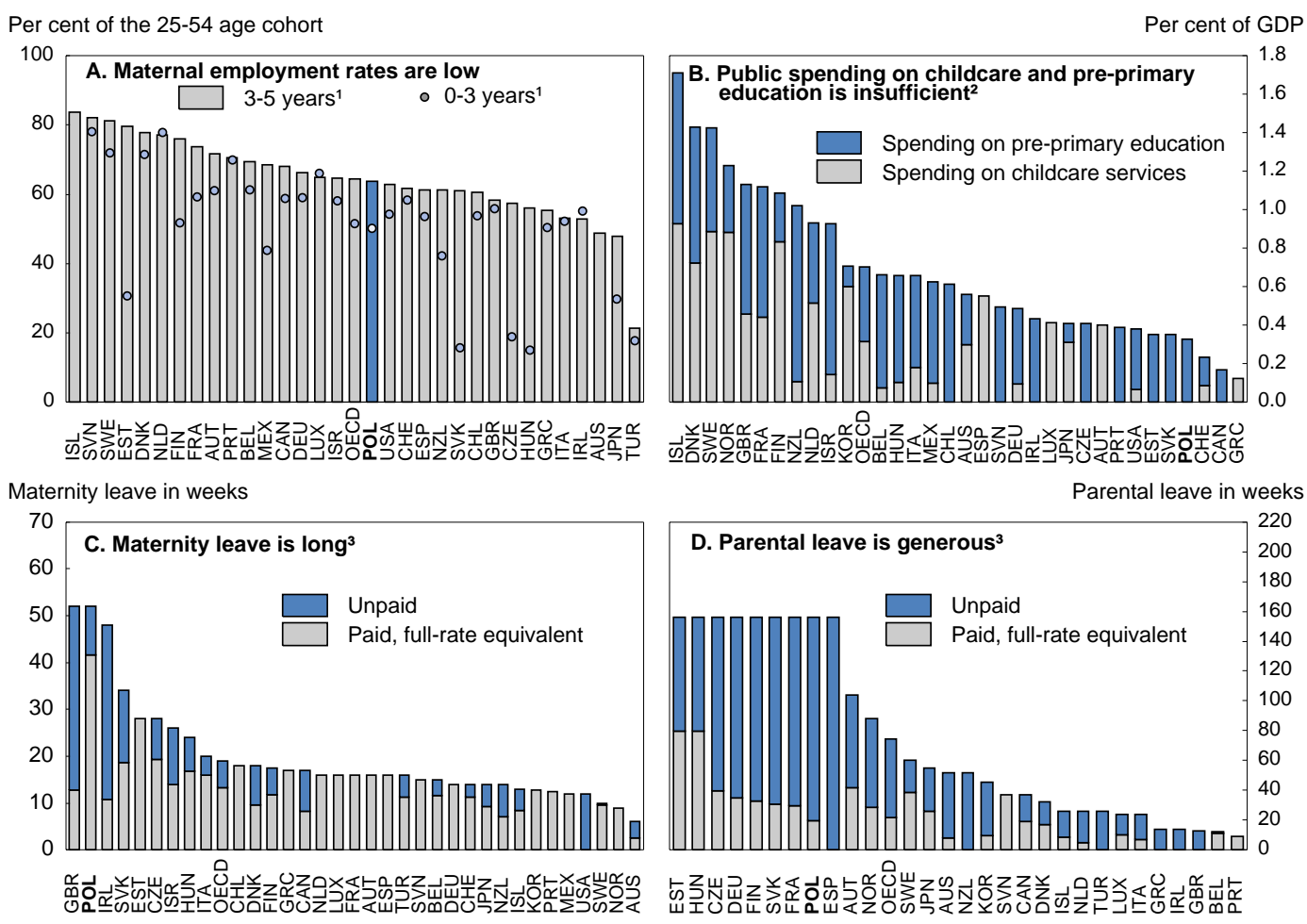

1. Age of the youngest child.

2. Disaggregated spending data are not available for Spain.

3. Child-related leave periods by duration of unpaid leave and the duration of the full-rate equivalent of the leave period; it should be noted that the 52 weeks of Poland's data point are the result of the 2013 reform further extending maternity leave in Poland.

Source: OECD Family database.

\section{Migration-related issues}

Emigration flows picked up very quickly after Poland's accession to the European Union in 2004 and the opening of most EU labour markets to workers from new member states. Keeping in mind that migration numbers are not well measured, in 2007 there were an estimated 2.3 million Polish citizens, or $6 \%$ of the total population, staying temporarily abroad, compared to 1.0 million in 2004 (Kaczmarczyk, 2012), when the magnitude of annual net outflows was similar to that in the 1980s (Figure 18, Panel A). Overall, the increase in the stock of emigrants since 2004 is equivalent to about $4.1 \%$ of the working-age population. With the world economic crisis and Poland's good relative performance, this trend has partly reversed (Panel B). A stronger propensity to migrate abroad has been observed among young people who originate from economically backward areas, giving some credit to the idea that emigration was a response to the oversupply of labour. Yet, emigration since 2004 has fuelled labour shortages in specific occupations, such as construction, retail trade and health care. Between 2004 and $2009,5.8 \%$ of physicians, $2.6 \%$ of dentists and $3.4 \%$ of nurses were delivered a European certificate of professional qualification, a good proxy of their propensities to emigrate (Okolski and Topinska, 2012). The most extreme case was anaesthesiologists, about $19 \%$ of whom requested such a certificate. 
Figure 18. Migration indicators

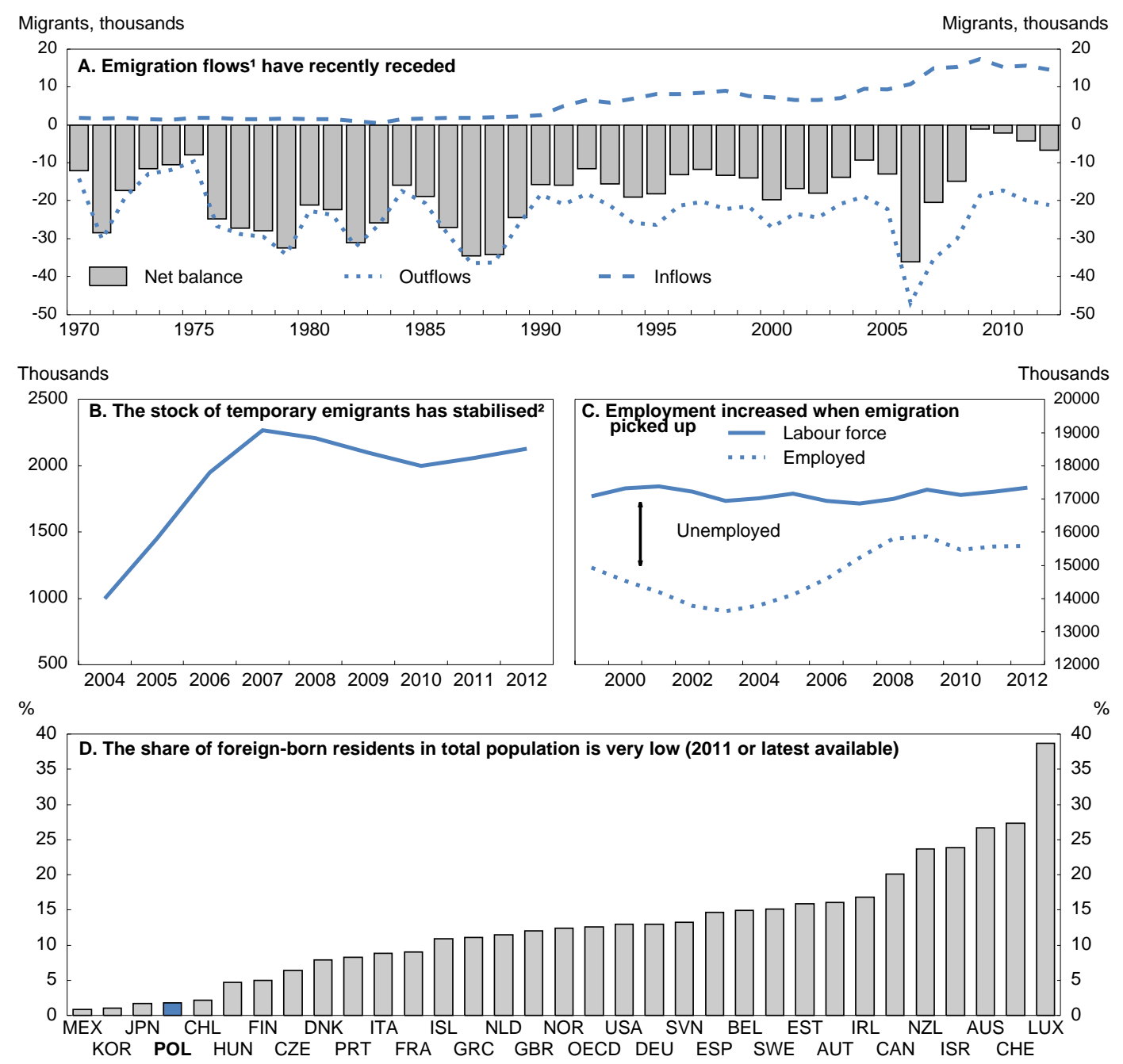

1. For permanent residence.

2. Estimates of the number of Polish citizens staying abroad for longer than three months (two months in years prior to 2007).

Source: GUS; OECD International Migration Outlook 2013.

Although significant, this increase in emigration flows had only a mild short-to-medium-term impact on the Polish labour market (see, among others, Budnik, 2008, Ingham and Ingham, 2011, Kaczmarczyk and Okolski, 2008, and Kaczmarczyk, 2012). It is true that during the 2004-08 period the unemployment rate decreased sharply (Figure 1, Panel D). However, the start of the decline preceded the emigration wave. Moreover, to a large extent, the reduction in the number of unemployed since 2004 is accounted for by higher employment than a decrease in the labour force (Figure 18, Panel C). Worker outflows are likely to have generated wage pressures, but they seem to have been limited (Budnik, 2008; Kaczmarczyk, 2012). As shown above, at the aggregate level, real wages did not keep pace with labour productivity advances.

Emigration might have two serious adverse consequences over the long term: a brain drain and the amplification of unfavourable demographics. The extent of the former problem is likely to be limited. Only $20 \%$ of post-EU-accession emigrants have a tertiary-education level compared to $15 \%$ in the overall population (and 15\% in the pre-accession period) (Kaczmarczyk, 2012). Hence, while emigration might 
reinforce skills mismatches, the aggregate quantitative impact is probably small. More serious is the negative impact on long-term GDP and GDP per capita due to a lower working-age population, especially in an emigration country like Poland where the population will soon be ageing quickly, and where, despite the recent increase, immigration flows remain low. The share of immigrants in total employment was the lowest among OECD countries at $0.2 \%$, compared with $12.0 \%$ on average in the OECD in 2012 . That share was also low in other CEECs, but greater than in Poland: $2.9 \%$ in the Czech Republic, $2.2 \%$ in Hungary and $0.5 \%$ in the Slovak Republic (see also Figure 18, Panel D).

The prospects for rapid population ageing and skills shortages, and possibly continuing robust emigration flows, have raised political awareness about the smoothing role of well designed migration policies. To facilitate the return of emigrants, several actions were taken, including information campaigns about administrative procedures and local job markets, but they had only moderate success. Given the still high structural unemployment rate, however, attracting immigrants has not been seen as a pressing issue. Besides, over time the most efficient policy action to limit emigration is to adopt policies that bolster employment opportunities at home and firms' competitiveness, and speed up convergence in standards of living with the most developed countries, thereby reducing the strength of the pull and push emigration forces. This includes removing the obstacles to internal migration discussed above, as internal and external migration are often substitutes. For example, expensive housing in urban areas has restricted internal labour mobility and is often considered to have been an important driver of buoyant post-2004 emigration flows above and beyond greater income prospects.

Although encouraging immigration could be particularly relevant for Poland, its effects on the structure of the population might be mainly temporary (even though they can extend over a generation), as migrants themselves eventually age. Moreover, since the population 15 to 64 is projected to decrease by $27 \%$ over $2010-50$, immigration alone, while useful, can only attenuate this process to a limited extent, and other policies boosting the labour utilisation of the working-age population will be needed.

To address short-term labour shortages, in 2006 workers from Ukraine, Belarus and Russia were given the right to work in Poland without permits for three months in any six-month period. In 2008, the scheme was extended to six months of work over a 12-month period, and opened to other Eastern European countries (Moldova, Georgia and recently Armenia) who also gained access to work permits. The procedure that employers must follow was simplified in 2009. However, long-term immigration is restricted: a residence permit can be acquired only after five years of uninterrupted legal residence in Poland, or two years if married to a Polish citizen for at least three years (Iglicka and Ziolek-Skrzypczak, 2010). After public consultation, in July 2012 the Government adopted a document entitled "Migration policy of Poland - the current state of play and further actions". Overall, Poland still lags other EU countries in implementing an overarching integration policy and in developing services for immigrants (Iglicka and Ziolek-Skrzypczak, 2010). Some experts consider that, despite the frequently advocated need for it (Okolski and Topinksa, 2012), a single comprehensive strategy to address migration issues has not yet been worked out.

\section{Boosting youth employment prospects}

\section{Youth unemployment remains stubbornly high}

Despite Poland's good overall economic performance in the recent past, youth unemployment remains stubbornly high (Figure 19, Panels A-C). By reducing the labour force participation of the high skilled (a composition effect), high education enrolment combined with a limited share of part-time work while studying contributes to this high unemployment rate (Panels D-F). While the rise in educational attainment (OECD, 2013e) has been a major achievement, the increase in the supply of high-skilled workers does not seem to have outpaced the shift in demand towards those with greater skills. Controlling for age and 
gender effects, the influence of tertiary education attainment on employment rates is one of the largest among OECD countries (Box 1). Moreover, the earnings premium of tertiary education has been more or less stable at a high level - between 65 and $80 \%$ - since the beginning of the 2000s against an OECD average of $45-60 \%$ (OECD, 2013f).

Figure 19. Youth unemployment
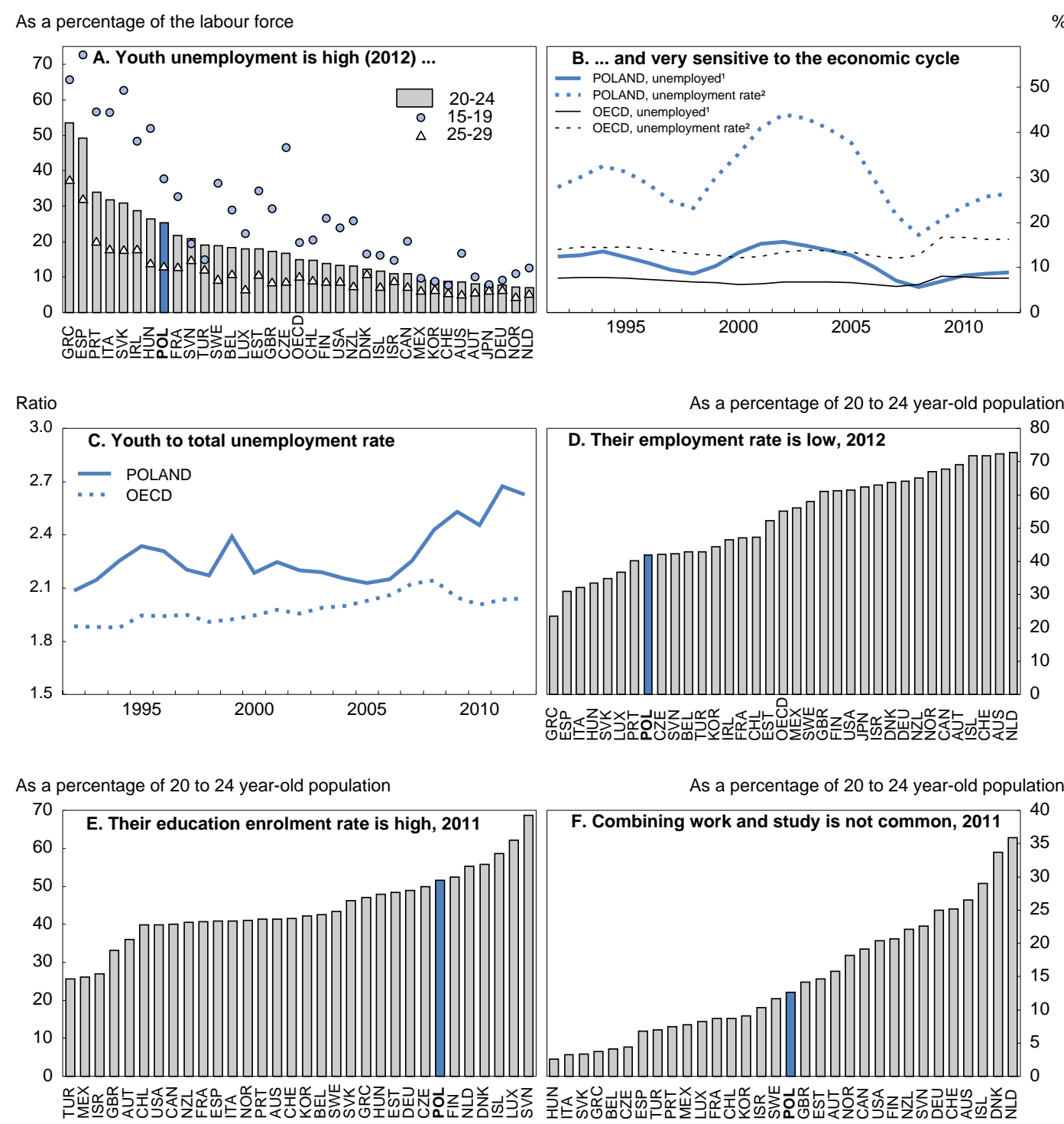

1. As a percentage of the population aged 15 to 24 years.

2. As a percentage of the labour force aged 15 to 24 years.

Source: OECD, Labour Force Statistics (2013) and Education (2013) Databases.

The school-to-work transition is slow. In many countries the first contact with the labour market occurs when students take jobs, but this is not the case in Poland (OECD, 2009). In 2011, only 24\% of Polish students aged 20-24 held a job, compared to about $65 \%$ in the Netherlands and Australia. Entry-level jobs are not commonly part-time, which is likely to complicate the transition to work (OECD, 2009). Less-educated workers in particular tend to go through an arduous transition. 


\section{Box 1. Impact of education attainment on employment rates}

To derive this effect the following specification was estimated for each country for 2011 :

$$
E R(i, j, k)=e(i)+f(j)+g(k)+u(i, j, k)
$$

where $E R(i, j, k)$ is the employment rate for age group $i$, gender $j$ and education level $k, e, f$ and $g$ are fixed effects controlling for these dimensions, respectively, and $u$ is a residual. Three educational attainment levels are considered: below upper secondary (primary and lower secondary education), upper secondary and tertiary with the upper secondary level used as the reference, i.e. $g(k=$ upper secondary $)=0)$. Compared with the raw employment rates by education level, the estimated fixed effects $g(k)$ enable adjustment for composition effects due to age and gender. Figure 20 shows the estimated fixed effects corresponding to the below upper secondary level (Panel A) and the tertiary level (Panel B). For Poland as an example, controlling for age and gender, a tertiary education level increases the employment rate by over 16 percentage points, the highest differential within the OECD, while not reaching the upper-secondary level diminished the employment rate by about 19 percentage points, also rather high.

Figure 20. Educational attainment shapes employment prospects relatively heavily

Coefficient estimates
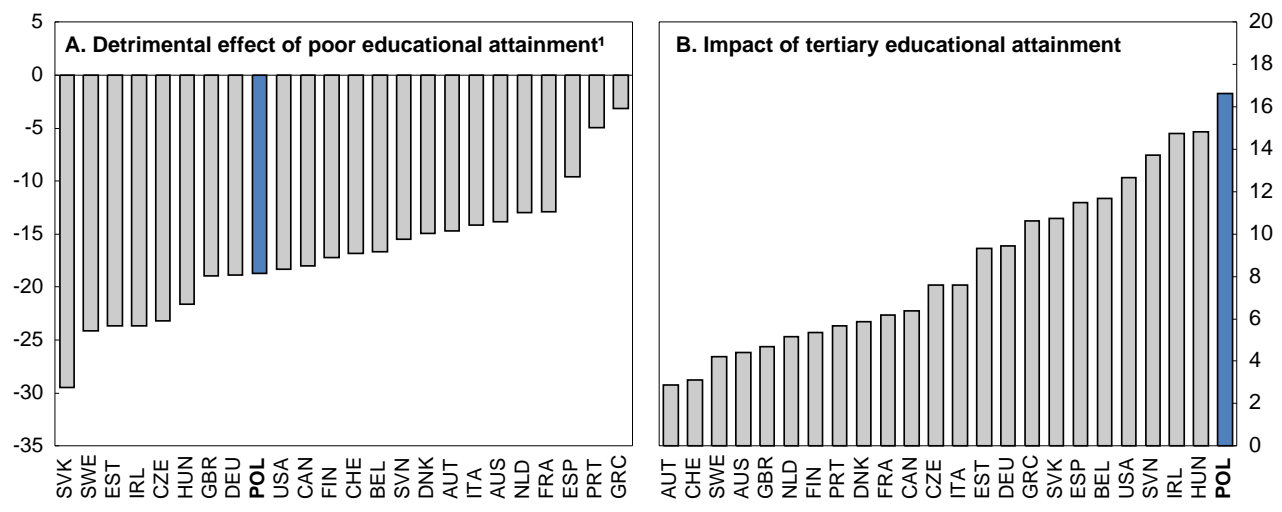

1. Primary and lower secondary education.

Source: OECD calculations.

\section{Precarious forms of employment should be reduced}

Temporary contracts are widespread, and precarious employment is pervasive among young workers. With two-thirds of employed youth not having a permanent contract, temporary work is more prevalent among youth than in most OECD countries (Figure 8, Panel C). According to Chancellery of the Prime Minister (2011), over 50\% of workers between 18 and 32 are employed under a civil-law contract. This situation is tolerated more than chosen: the incidence of involuntary temporary work reached $39 \%$ of employed youth in 2011, the third-largest share of OECD countries after Spain and Portugal (OECD, 2013g). That could help explain why, a few years ago, Polish youth seem to have been particularly pessimistic about their society's and their own futures (Figure 21), which might in turn fuel emigration.

While the possibility of civil-law contracts, weak protection provided by fixed-term contracts (FTCs) and low costs of dismissing limited-tenure employees might promote the hiring of new entrants, young Polish workers, and especially the unskilled, bear a disproportionate share of the social costs generated by the deep segmentation of the labour market (Figure 8). Poland is the OECD country where the sensitivity 
of youth unemployment to the business cycle is the strongest (Figure 22). Such labour-market duality might be detrimental to economic performance, as it generates erratic pathways towards stable employment and may result in underinvestment in human capital. Temporary contracts do not seem to serve as a springboard to stable employment in Poland (OECD, 2009; Polakowski, 2012), but rather as a screening device (Baranowska et al., 2011).

Figure 21. Young people are pessimistic for the future ${ }^{1}$

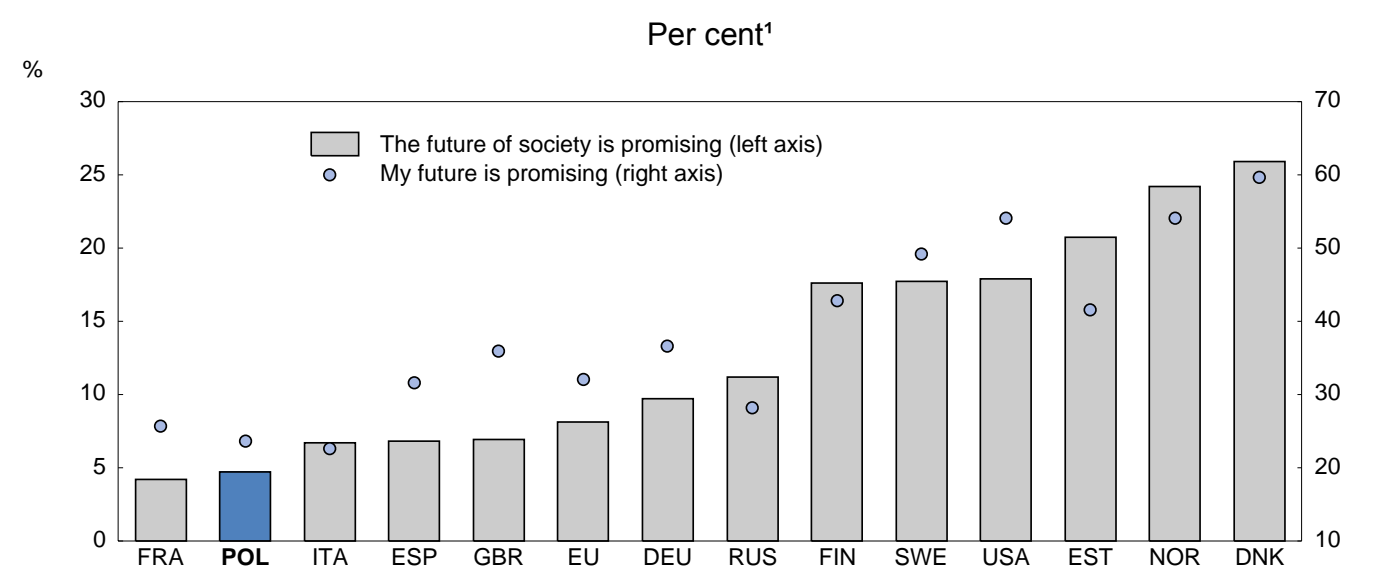

1. Percentages agreeing with each statement.

Source: Les jeunesses face à leur avenir: une enquête internationale, Fondation pour l'Innovation Politique, 2008.

Figure 22. Youth unemployment rates are deeply affected by cyclical developments

Total change in unemployment rate due to a permanent shock of 1 percentage point of GDP

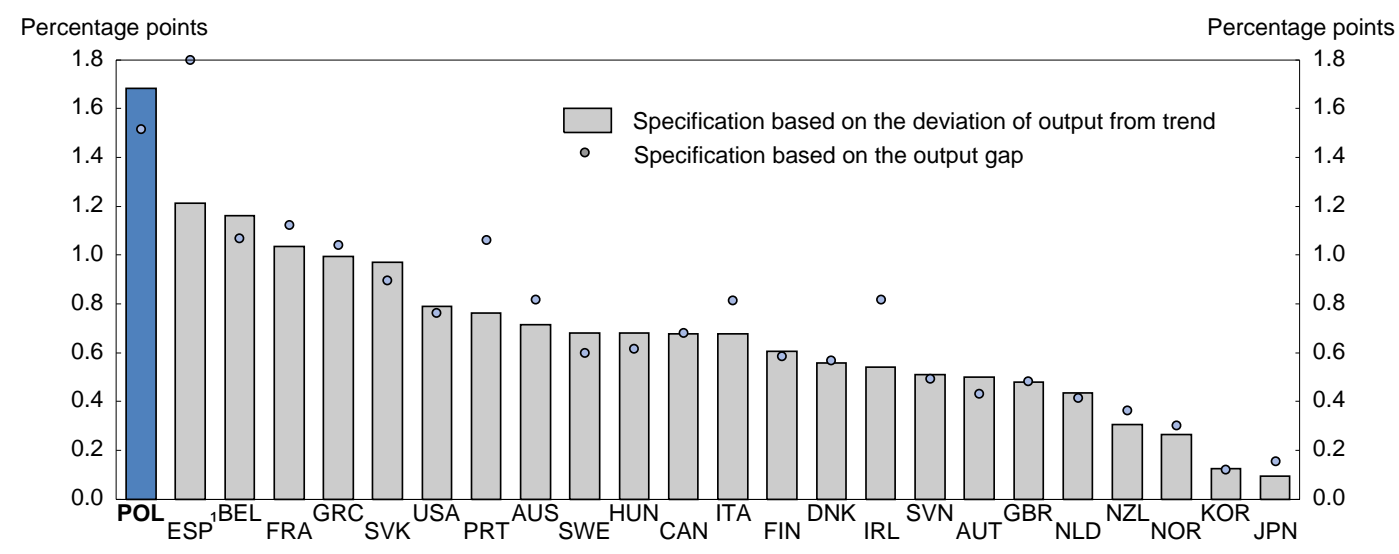

1. Reported estimated changes in the youth unemployment rate have been capped at 1.8 points to improve the readability of the graph, the true value being 2.4 for Spain (based on the output gap).

Source: Boulhol and Sicari (2013a), "Labour market performance by age groups: a focus on France", OECD Economics Department Working Papers, No. 1027.

A worker taking up his/her first job can be paid $80 \%$ of the minimum wage for the first year. While this provision has no age limit, it effectively increases demand for younger workers. Such a scheme is useful. However, a potential wage increase of $25 \%$ after the first year might be too sharp, inducing substitution effects, which might generate work instability. Hence, smoothing the transition by allowing a pay floor of, say, $90 \%$ of the minimum wage for the second year might be worth considering. In addition, the scheme could also be extended to the long-term unemployed. 
ECO/WKP(2014)20

\section{Fostering a better school-to-work transition}

Whereas youths tend de facto to be excluded from unemployment benefit (UB), given strict eligibility rules, they have incentives to register with the PES. Indeed, registering opens up to them, on top of the usual range of PES services (information about job vacancy, internship, on-the-job training, subsidised jobs), a scholarship of $50 \%$ of the basic UB level (for young people under 26 without qualification, means-tested) and public health insurance coverage (OECD, 2009). In terms of ALMPs, the largest youth programme (although since 2009 it has been open to all unemployed, irrespective of age) is the apprenticeship system (different from that developed within Vocational Education and Training, VET). These are specific contracts not exceeding 12 months, supervised by local labour offices and paid $120 \%$ of the standard UB level. Another programme, Intervention Works, based on wage subsidies for private employers seems prima facie to be giving good results in terms of employment after completion, but one should be cautious about extending such schemes as they are subject to large deadweight losses when they are not well targeted (Martin and Grubb, 2001). Given their short labour-market experience, unemployed youths need to have access to a well functioning PES (see above), and OECD (2009) emphasised that too few of them benefit from ALMPs in Poland.

Integrating youths who leave the school system without completing their studies, and the less-skilled more generally, is a difficult task. Intervening after the student has left school is very costly and the results often disappointing, so it is important to wage this battle earlier, at school (see below). For dropouts, early action is particularly important, and job-search strategies that are based on reciprocal obligations are often found to be the most cost-effective (Quintini et al., 2007). One challenge is to detect early signs of loss of contact with the world of work and to intervene rapidly, because course corrections become complicated when a young person is socially marginalised. Training, which is generally less effective in the case of dropouts, must be tailored and calibrated to labour market needs as much as possible. In this area, social-partner involvement may prove beneficial (Quintini et al., 2007). Co-ordination between the PES and educational authorities is crucial to rapid intervention with youths who are in danger of losing their bearings. The Netherlands, Norway and the United Kingdom have recently bolstered this co-ordination in order to more quickly identify and offer a solution to youths quitting school prematurely (OECD, 2011b).

\section{Important mismatches persist, despite human-capital deepening}

It is generally perceived that there remains in Poland a wide gap between the skills produced by the education system and those that are required by firms. Beyond the recent cyclical contraction in labour demand, a lack of skills is indeed often viewed by Polish employers as the most important constraint on firm activity. Rutkowski (2011) documents the shift of labour demand away from less skilled manual to more skilled white-collar labour following the economic transition. The current skills shortages, resulting from this needed job-reallocation process, would apply to both "hard" skills, such as technical qualifications and competences, and "soft" skills, such as the capacity to work in a team, job attitudes and behavioural skills. Moreover, innovative firms tend to be the most affected by skill shortages. While shortages and hiring difficulties of high-skilled white-collar workers are the most obvious, despite human-capital deepening, employers also find it difficult to hire skilled blue-collar workers, notwithstanding the excess supply (and high unemployment) of blue-collar workers more generally (Rutkowski, 2011). The poor employment prospects of workers with secondary general education points to weak labour demand for general skills that are not accompanied by technical or vocational skills. Education has unfortunately been more oriented towards theory than practice, and the link between the two in curricula has been very weak (Chancellery of the Prime Minister, 2011).

Tackling mismatches requires a wide array of policy actions. The most far-reaching reform would involve greater responsiveness by the education system to labour market needs. On-the-job training and lifelong learning can also play a great role in adapting workers' skills to a rapidly changing technological 
environment and thereby in preventing the entrenchment of under-skilling. For example, the participation of low-skilled youth in non-formal education is very low (Figure 23). In as much as skill shortages might have been amplified by emigration, encouraging well targeted immigration could help to fill skills gaps. Enhancing job-matching services, including through better job-market information, and fostering labour mobility would also help to reduce mismatches. In addition, the prevalence of FTCs for youth is likely to hinder the development of such "soft" skills as commitment, reliability, responsibility and motivation.

Figure 23. Participation in non-formal education is minimal

Participation rate of the 25-34 and 25-64 year-old age groups, 2008 or latest year available
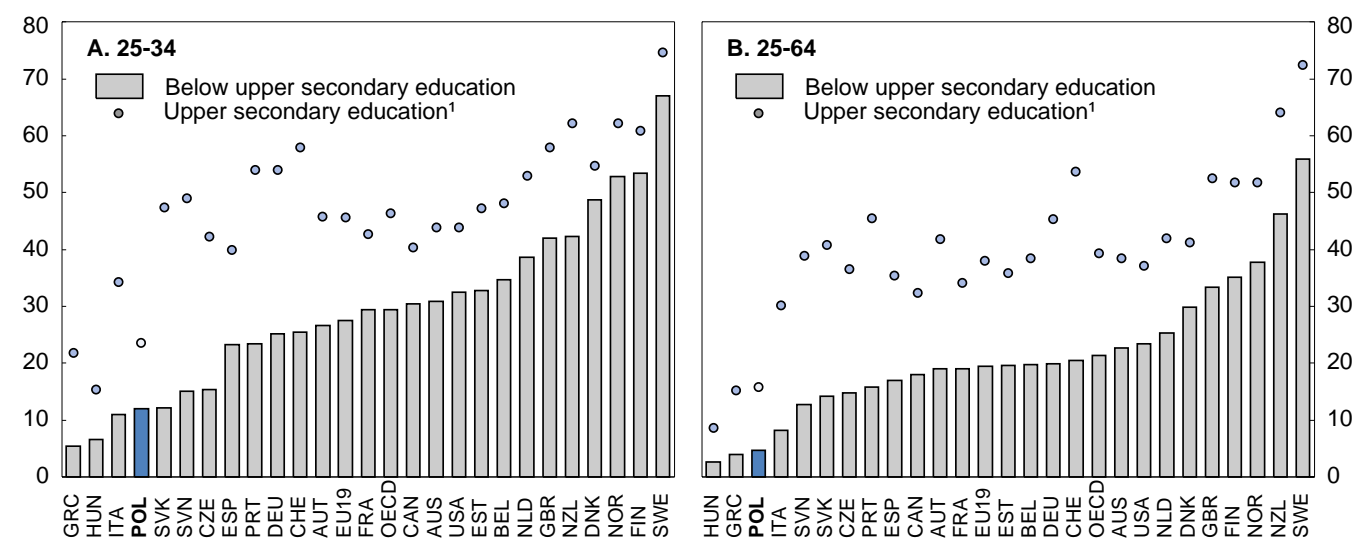

1. Including post-secondary non-tertiary education.

Source: OECD, Education at a Glance 2012 database.

\section{Further improving education outcomes}

Following the reforms undertaken after transition, the improvement in education performance has been impressive. Average PISA scores rose between 2000 and 2012, when Poland ranked slightly above the OECD average. This achievement came mostly from progress recorded by the poorest performing children, which has reduced inequality of education levels markedly (Boulhol and Sicari, 2013b). Between 1989 and 2011, the number of tertiary education students also grew fivefold. Despite these impressive advances, some important challenges remain.

First, while pre-school enrolment rates have increased substantially recently, they remain low (Figure 24 and OECD, 2013d), especially in rural areas. Yet, investment at an early stage yields the highest returns, especially for children from disadvantaged backgrounds where the development of interpersonal skills and discipline gets little encouragement (Heckman, 2008). This is because learning is a cumulative process: actions taken during early childhood have long-lasting effects that can enhance social skills and learning abilities (Heckman and Carneiro, 2003). Developing pre-school facilities therefore remains a top priority. As discussed above, recent changes go clearly in the right direction.

Second, the VET system, which enrols about one third of upper-secondary students, needs to be improved. Since the mid-1990s there has been a large outflow from vocational education towards general education (Polakowski, 2012). Yet, although Poland has one of the lowest dropout rates in the OECD, graduates who have completed just general secondary education or basic vocational schooling are often ill-prepared for the labour market because of a lack of practical training (OECD, 2008a). VET has lost some of its attractiveness due to the failure of most schools to modernise their programmes and equipment sufficiently rapidly. Moreover, as shown by the German example, one key aspect lies in the involvement of social partners in VET policy and provision, and in the quality of social dialogue (Quintini et al., 2007). It 
is critical that VET programmes retain strong elements of work-based learning (OECD, 2013f), but Polish VET relies mostly on school-based programmes, with only a small share of VET students (about 17\%) combining school and work (OECD, 2010b).

Figure 24. Enrolment rate in pre-primary education is rising but remains low

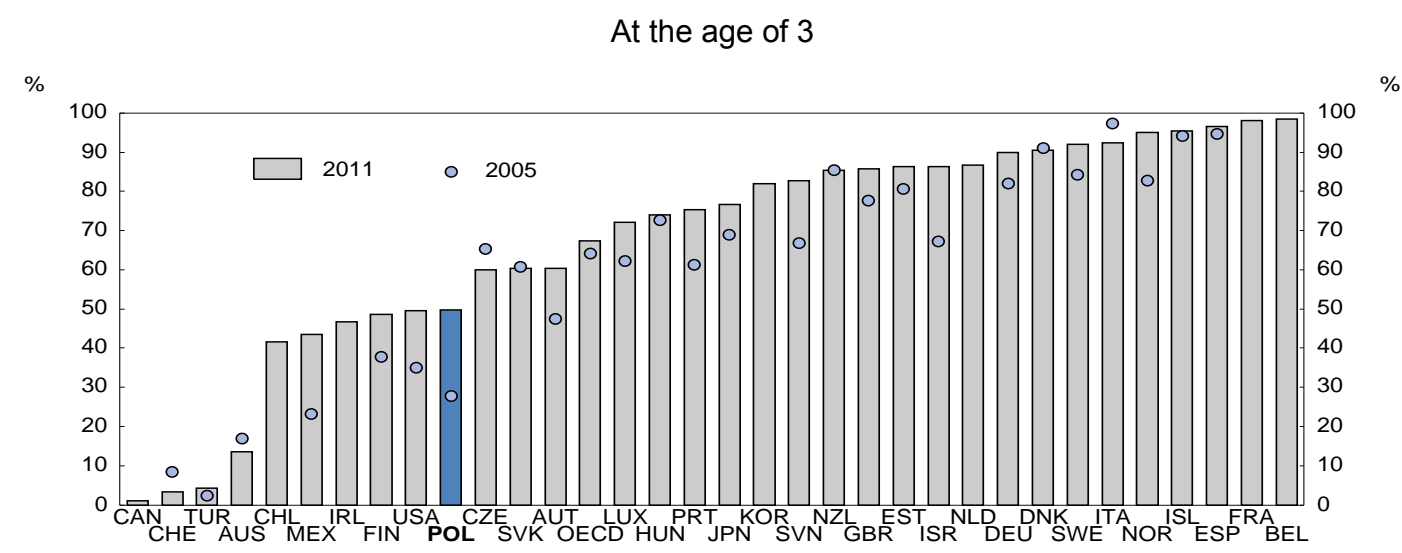

Source: OECD, Education at a Glance 2013 database.

The government recognises the need to enhance the VET system and introduced changes in 2012. The aim is to foster employers' involvement in the curriculum and in conducting courses and examinations, and to create more flexible courses. It is too early to assess the scope and impact of the implemented changes. However, more could be done. For example, firms' managers could be appointed to school boards. Also, the European Commission (2013) pointed out that more forceful action is needed involving greater public money to reimburse employers' training costs and to expand the enrolment capacity of VET schools, and raising the quality of teaching.

Third, the OECD Review of Polish Tertiary Education (OECD, 2007) highlighted vocational tertiary education as an area of serious weakness. Although the tertiary education system includes vocational Higher Education Institutions (HEIs), their specific role in meeting labour demand is not fully exploited, although the 2011 higher education reform brought significant progress. It introduced an obligation by HEIs to choose between academic curricula emphasising theoretical modules and practice-oriented curricula based on practical modules and strengthened participation of employers' representatives. HEIs were granted more autonomy, as they are now entitled to create their own study programmes based on the National Qualifications Framework for Higher Education. This framework improves the HEI evaluation process carried out by the Polish Accreditation Committee.

Moreover, graduates' early careers must be monitored by HEIs. A system of quality-based financing was introduced, amounting to about $2 \%$ of tertiary education spending, and HEIs are required to fill research and teaching vacancies competitively. The reform also includes measures to strengthen the links between HEIs and businesses, and a programme has been launched to attract students to economy-relevant areas, including information technology, chemistry, mathematics, construction and biotechnology, given that students often choose courses in social science, humanities, law and economics irrespective of often disappointing job prospects. A 2013 draft amendment to the Higher Education Law would, if implemented, enhance employers' involvement in both the design of the curricula and the teaching process, introduce a three-month obligatory internship for students opting for the practice-oriented curricula, create a central system to track graduates' employment outcomes and allow the validation of learning outcomes achieved outside the formal system. With Germany and Finland providing useful examples of well functioning vocational tertiary education (OECD, 2007), the authorities should make further efforts to promote a 
distinct vocational sector, as intended by the 2013 draft amendment, which would introduce a clear distinction between academic and vocational HEIs.

Fourth, with about 440 higher education institutions, tertiary education is very fragmented. The split between fee-based private universities (accounting for about a third of students) and public universities that charge no tuition fees is unfair and distorts competition. Beyond the funding advantage, public universities enjoy a much better reputation as well as greater physical capital and better human resources inherited from the past. They can therefore select the best students. Moreover, they also provide fee-based programmes that are not called full-time daily studies, as those have to be free of charge according to the constitution. Past Surveys of Poland (OECD, 2006b; O'Brien and Paczynski, 2006; OECD, 2008a) recommended that the authorities: put the financing of public and private HEIs on an equal footing; introduce cost-related tuition fees in the public sector; simplify access to the dysfunctional student-loans system, whose repayment should be income-contingent; allocate academic positions based on transparent and competitive procedures; and systematically assess HEI quality. In October 2012, mandatory payments for the second and additional degrees were introduced at public HEIs.

\section{Continuing to enhance the supply of senior workers}

The employment and participation rates of older workers have both risen strongly since the mid-2000s (Figure 25). For the 50-54 and 55-59 age groups, employment rates increased by 13-19 percentage points between 2004 and 2012 for both men and women. For 60-64 year-olds, the improvement is only half as large for men, while it is virtually nil for women, who still face attractive public pension provisions. Yet, the current levels remain well below OECD averages (Table 2). Figure 4 (Panel D) shows that even within the poorly performing group of countries with a similar age structure of employment rates, Poland's drop-off starts from the 45-49 age group, and its decline is steeper. The OECD is carrying out a new review of Polish policies to encourage greater labour market participation at older ages by fostering employability, job mobility and labour demand; it is set to be published at the end of 2014 (OECD, 2014).

Figure 25. Employment and participation rates for older workers have increased from low levels
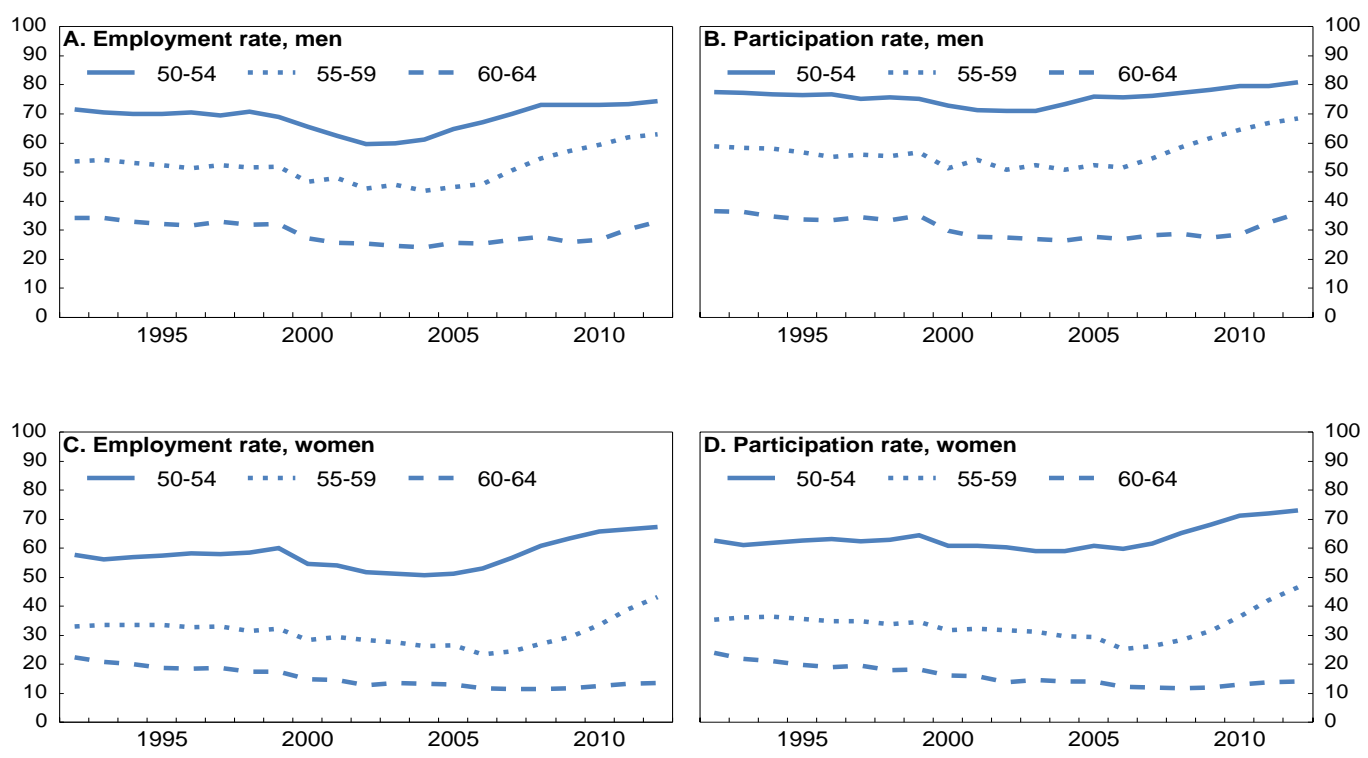

Source: OECD, Labour Force Statistics 2013 Database. 
ECO/WKP(2014)20

Table 2. Older workers scoreboard, 2002, 2007 and 2012

\begin{tabular}{|c|c|c|c|c|c|c|}
\hline & & oland & & & $\mathrm{OECD}^{1}$ & \\
\hline & 2002 & 2007 & 2012 & 2002 & 2007 & 2012 \\
\hline Employment & & & & & & \\
\hline Employment rate, $50-64$ (\% of the age group) & 40.3 & 43.4 & 49.4 & 56.3 & 60.2 & 62.0 \\
\hline of which: $55-59$ & 35.9 & 36.8 & 52.6 & 57.1 & 62.1 & 65.8 \\
\hline $60-64$ & 18.6 & 18.4 & 22.6 & 33.5 & 37.8 & 41.0 \\
\hline Gender gap in employment, 55-64 (ratio men/women) & 1.7 & 2.1 & 1.7 & 1.8 & 1.6 & 1.4 \\
\hline Employment rate, $65-69$ (\% of the age group) & 10.8 & 8.5 & 9.5 & 15.6 & 17.2 & 19.3 \\
\hline Job quality & & & & & & \\
\hline Incidence of part-time work, $55-64$ ( $\%$ of total employment) & 22.1 & 18.5 & 11.6 & 17.1 & 17.7 & 18.4 \\
\hline Incidence of temporary work, 55-64 (\% employees) & 11.6 & 19.9 & 21.8 & 9.3 & 9.4 & 8.9 \\
\hline Incidence of self-employment, $55-64$ (\% of total employment) & 42.0 & 36.4 & 30.1 & 30.2 & 27.1 & 26.1 \\
\hline Full-time ${ }^{2}$ earnings, $55-59$ relative to $25-29$ (ratio) & 1.39 & 1.61 & - & 1.32 & 1.34 & 1.34 \\
\hline Effective labour force exit age ${ }^{3}$ (years) & & & & & & \\
\hline Men & 61.1 & 61.4 & 62.3 & 63.3 & 63.7 & 64.2 \\
\hline Women & 59.0 & 57.7 & 60.2 & 61.3 & 62.3 & 63.1 \\
\hline Unemployment & & & & & & \\
\hline Unemployment rate, 55-64 (\% of the labour force) & 10.5 & 6.8 & 7.4 & 4.7 & 4.0 & 6.0 \\
\hline $\begin{array}{l}\text { Incidence of long-term }{ }^{4} \text { unemployment, } 55+(\% \text { of total } \\
\text { unemployment) }\end{array}$ & 57.7 & 57.0 & 43.9 & 43.6 & 45.9 & 46.9 \\
\hline Employability & & & & & & \\
\hline Share of $55-84$ with tertiary education ${ }^{5}$ (\% of the age group) & 12.7 & 12.3 & 12.8 & 20.0 & 21.1 & 23.8 \\
\hline Participation in training, ${ }^{6} 55-64$ & & & & & & \\
\hline Absolute (\% of all employed in the age group) & 1.5 & 2.1 & 1.8 & 6.3 & 8.1 & 9.4 \\
\hline Relative to employed persons aged 25-54 (ratio) & 0.23 & 0.31 & 0.31 & 0.43 & 0.54 & 0.57 \\
\hline
\end{tabular}

1. Unweighted averages for 34 OECD countries.

2. Mean gross hourly earnings, 1998 and 2004.

3. Effective exit age over the five-year periods 1997-2002, 2002-07 and 2007-12.

4. Unemployed for more than one year.

5. 2005, 2007, 2011.

6. Job-related training during the last month in 2001, 2007, 2011.

Source: OECD estimates from national labour force surveys, EU-LFS and OECD Education database.

\section{Eliminating special old-age pension regimes}

The sharp tightening of early-retirement conditions in 2008 has boosted the labour supply of older workers (OECD, 2010a). As a result the average effective retirement age increased from 57.1 years in 2007 to 59.8 in 2011. Nevertheless, it remains too low due to the low statutory female retirement age, the slow phase-in of the 2008 reform tackling early retirement and the existence of special regimes. In 2011 almost $80 \%$ of old-age pensions were managed by ZUS, $17 \%$ by KRUS and the remainder by the Ministries of Internal Affairs, Defence and Justice (Martinez-Fernandez et al., 2013). Out of the people beginning to receive an old-age pension from ZUS in 2011, the average effective retirement age was 60.1 years for men (against a legal age of 65) and 59.5 for women (against 60) (Table 3). This is because about $12 \%$ of men who retired were miners with an effective retirement age of 47.9 years. Also, those who had worked for 20-25 years before 1999 in specific work conditions remain entitled to early retirement. That scheme will vanish gradually, but a hefty $60 \%$ or so of new male retirees in ZUS, excluding miners, fall under it. As a result, in 2011, only about one quarter of new male retirees were at least 65 , the statutory retirement age.

The main special retirement regimes cover farmers, miners, railway workers, uniformed services and judges. Miners can retire after 25 years of work. Until the 2012 reform, soldiers and police officers could retire after 15 years, but now uniformed officers will be able to retire only at age 55 and only provided that they have worked for at least 25 years. Moreover, the pension will depend on earnings for 10 consecutive years instead of the final salary as at present. The reform will apply to those who start their service after 
1 January 2013, hence a very long phase in. As discussed above, the changes to the farmers' regime have been very limited.

Table 3. Pensions granted in 2011 - Social Insurance Fund

\begin{tabular}{lrrr}
\hline \multicolumn{1}{c}{ Age } & Total & Male & Female \\
\hline & & & \\
Total & 102466 & 56653 & 45813 \\
49 and less & 5296 & 5175 & 121 \\
50 & 2024 & 1938 & 86 \\
51 & 432 & 285 & 147 \\
52 & 375 & 161 & 214 \\
53 & 407 & 122 & 285 \\
54 & 479 & 128 & 351 \\
55 & 8052 & 475 & 7577 \\
56 & 1642 & 205 & 1437 \\
57 & 1501 & 152 & 1349 \\
58 & 956 & 116 & 840 \\
59 & 1152 & 106 & 1046 \\
60 & 53344 & 25746 & 27598 \\
61 & 5152 & 2952 & 2200 \\
62 & 3144 & 1990 & 1154 \\
63 & 1657 & 1219 & 438 \\
64 & 1621 & 1325 & 296 \\
65 and more & 15232 & 14558 & 674 \\
Average age in years & 59.8 & 60.1 & 59.5 \\
\hline
\end{tabular}

Source: Social Insurance Fund database.

\section{Continuing to tighten disability pension schemes and better activate disabled workers}

Since the early-2000s the number of disability benefit recipients, among whom older workers are over-represented, has been divided by three from a very high level (Figure 26, Panel A). Farmers remain also over-represented, accounting for about $30 \%$ of beneficiaries. The eligibility criteria have been steadily tightened, the health status of the beneficiaries better verified and the benefit made temporary, with a maximum period of three years. These changes are also notable, since early-retirement schemes were also tightened during the same period, which could have led to a shift into disability support, as observed in other countries. They might be short-lived, however, since disability benefits will become more attractive. Indeed, under the 1999 old-age pension reform, replacement rates will be reduced, since, for a given retirement age, the old-age pension automatically decreases with improvements in life expectancy. As a result, the ratio of average disability to old-age pensions will increase significantly, boosting incentives to retire early under the former regime when possible (IMF, 2013). Therefore, the formula used to calculate disability pensions should be revised in line with that used for old-age or minimum pensions in order to account for life expectancy gains. The generosity of the benefits on the other hand is slightly below average: Poland spends about $1.1 \%$ of GDP on public disability pensions (against a hefty $4.2 \%$ in the mid-1990s), compared with an OECD average of $1.2 \%$.

Poland has the OECD's lowest employment rate of people with disabilities (Figure 26, Panel B). Moreover, about one-third of those employed work part-time, one of the OECD's highest shares (see Figure 2.3 in OECD, 2010c), even though part-time employment is low overall in Poland. Employers often prefer not to fulfil the $6 \%$ subsidised employment quota for disability benefit recipients and pay a fine (about $40 \%$ of the average wage for each worker below the quota). This suggests that, while the quota level could be reduced, there is some room to raise that penalty (in a budget-neutral way), which should also be differentiated to take into account the degree of disability of employed workers. With little vocational rehabilitation and training, and the emphasis put on employment by Sheltered Work Enterprises, which 
account for about two-thirds of subsidised employment of disabled people, benefit from overly generous tax breaks and help perpetuate the segregation of disabled workers, Poland's policy has traditionally been passive (OECD, 2006c). Better activating people with disability is rightfully a priority, as is recognised by the government.

Figure 26. Disability pensions
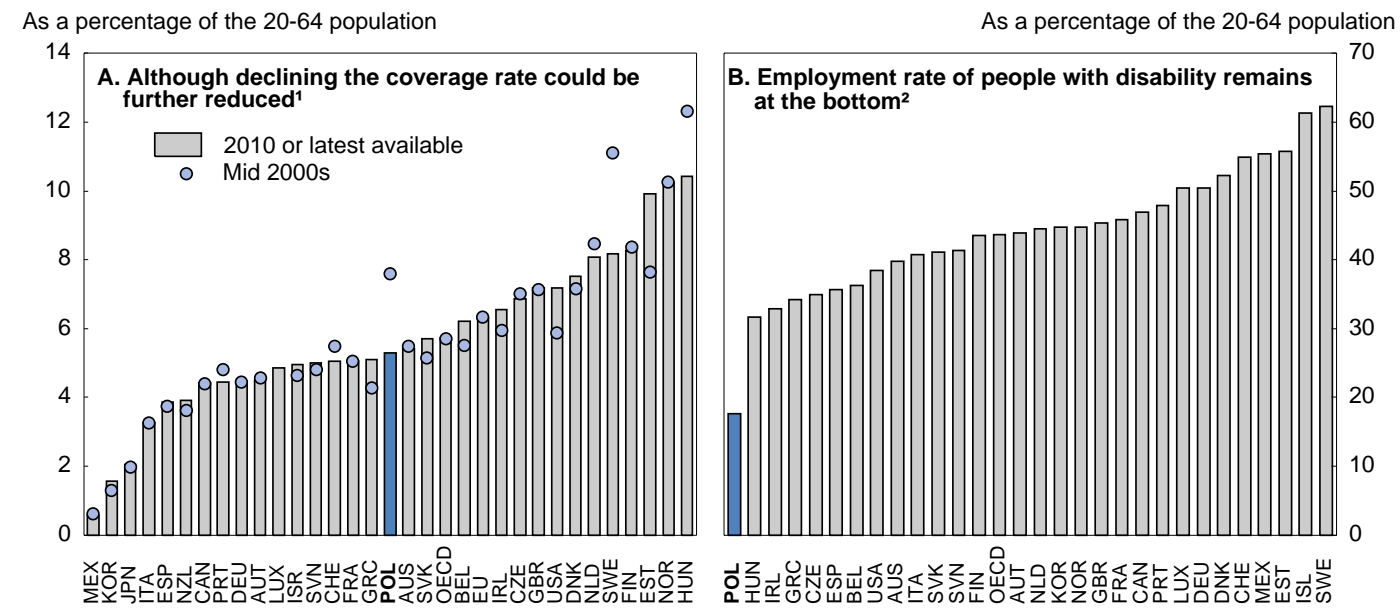

1. 2010 or latest available. Poland's data point refers to 2012 and is constructed assuming the number of disability benefit recipients in the KRUS changed in the same proportion as the total number of beneficiaries in ZUS since 2007, the latest year for which data for the KRUS are available.

2. Late 2000s.

Source: OECD, Going for Growth 2013; OECD SOCX database and OECD (2010), Sickness, Disability and Work, Breaking the Barriers.

Little or no progress has been achieved on the recommendations made following the OECD's 2006 in-depth review of work obstacles confronting people with disabilities in Poland (OECD, 2006c). First, the supply of well targeted and individualised high-quality services of vocational rehabilitation and training should be increased, and local labour offices should place greater emphasis on early intervention. Second, the structure of employment support should be overhauled by streamlining administrative structures and responsibilities in order to provide the disabled with timely and adequate support. Too many players are involved (ZUS, the PES, the State Fund for the Employment and Rehabilitation of Disabled People, or PFRON, and local governments), each with unclear responsibilities. PFRON and the PES are perceived as rather passive institutions in terms of dealing with disabled people, failing to combat their high level of inactivity (OECD, 2006c). The 2006 review recommended improving coordination regarding vocational training and re-qualification programmes between ZUS and the PES, placing the governance of PFRON under local governments' responsibility and having ZUS in charge of the entire disability assessment; currently they do so for income-support purposes only, and local governments perform them for labour-market purposes. Third, KRUS rules should be aligned with those in the general social insurance scheme: in the KRUS, disability is narrowly defined as the inability to continue to work on one's own farm. Even in the ZUS, the definition of partial disability is related to the inability to continue working in one's own profession and should be abandoned. Fourth, financial incentives to work should be improved by smoothing the phasing-out of disability benefits with higher earnings. Finally, special employment conditions for disabled workers, such as shorter working hours and longer annual leave entitlements, should be eliminated, as they represent employment obstacles for employers, are probably ineffective in boosting labour supply and reinforce stereotypes and prejudices (OECD, 2006c). 


\section{Removing some specific limitations to the demand and supply of older workers}

On the demand side, employers generally point at a disconnect between higher wages for seniors and lower productivity, due to illness, difficulties in adapting to technological changes, especially those induced by information technologies, and insufficient training. In 2011, labour costs were reduced, as the number of days of sick-leave benefits paid by employers was lowered from 33 to 14 (from the 15th day sickness benefit is paid by ZUS). Also, older workers on open-ended contracts are subject to a stricter employment protection, as they cannot be fired less than four years before their retirement age. This feature is a source of uncertainty and costs for firms and ends up limiting the recruitment of older workers. France, for example, had a similar albeit less strict regulation and did well in eliminating it in 2008.

On the supply side, the longer unemployment benefit (UB) entitlement for over-50 workers, discussed previously, should be eliminated. Beyond issues related to early retirement and disability, the government launched the "Generational Solidarity 50+" programme in 2008 to raise seniors' participation rate. The programme aims to improve working conditions, upgrade skills and qualifications, enhance activation policies targeted at the disabled and unemployed, and reduce labour costs of women aged above 55 and men above 60 through exemptions from unemployment insurance contributions (this also applies to hiring all unemployed over 50 for the first 12 months). The results of that programme have been somewhat disappointing, in part due to ALMP budget cuts since 2011 (IMF, 2012; Martinez-Fernandez et al., 2013).

\section{Implementing a broad and flexible system of lifelong learning}

Professional training and lifelong learning are critical to adapt skills to technological progress and the fast pace of on-going globalisation and to deliver the general competencies that might be needed over a person's career. Yet, despite generous EU funding, less than 5\% of Polish adults aged 25 to 64 participated in non-formal education and training in 2011, one of the lowest shares in Europe, with an even lower share for older or less educated workers (Figure 23, Panel B). Based on a report from the Ministry of Labour and Social Policy, the majority of employers do not invest in their workers' training: while in 2010 about $90 \%$ of large firms had prepared a training plan, this was the case for only about a third of micro and small firms (EWCO, 2010). This might result from a lack of SME resources and from time and credit constraints facing employers. It could also be due to SMEs' reluctance to invest in transferable human capital. All these explanations might signal a sub-optimal level of training, which would call for government intervention. However, even though training policies differ importantly across OECD countries, no consensus has emerged yet about best practice in this area.

Currently, several measures help low qualified and older workers to upgrade their qualifications or change occupations. Employers can receive government reimbursement for up to $50 \%$ of training costs and $80 \%$ for workers aged over 45 . The government is also considering the creation of a national training fund to provide for a greater share of training costs. Also, an amendment to the School Education Act passed in 2011 allows vocational schools to be integrated into the continuous education system, which will make it easier to obtain qualifications outside the school-based system. The New Core Curriculum at schools emphasises core competencies development, including mathematics, science, technology and the use of ICT. According to a 2013 draft law, universities would be able to validate the learning outcomes achieved in non-formal learning, thus facilitating access to higher education for people with at least five years of work experience. However, the elaboration of a broad and flexible system of lifelong learning that the OECD has recommended in recent Surveys (e.g. OECD, 2010a and 2012a), as part of an overarching strategy for a more competitive economy, is still missing. A strategic document on the "Prospects for Lifelong Learning" was published in March 2011, but, according to European Commission (2013), the responsibility for the strategy has continuously been shifted between ministries. In September 2013, the strategic document was adopted by the Council of Ministers. 


\section{Recommendations to boost employment}

\section{Policies other than labour market policies}

- Continue to develop transport infrastructure, in particular by upgrading the quality of the rail network. Reform housing policies by: making the release of zoning plans by municipalities mandatory; and replacing transaction taxes by ad valorem property taxes.

- Accelerate the reduction of government subsidies to the farmers' social insurance system.

- Downsize the informal economy by: simplifying tax regulations; reinforcing the monitoring and enforcement of the tax system; and eliminating the preferential regimes for the self-employed.

- $\quad$ Enhance product-market competition (Égert and Goujard, 2014).

\section{Labour market policies}

- $\quad$ Reduce labour market dualism by: making all contracts for labour services subject to the same tax and social contribution regime as Labour-Code contracts; extending the maximum length of trial-period contracts; streamlining legal dismissal procedures; setting a maximum duration for temporary contracts with the same firm; and easing regulation on temporary work agencies.

- Scale back survivors' pensions to reduce the labour tax wedge. Reduce wage rigidities by bringing the effects of age and education on public-sector wages closer to private-sector standards.

- Eliminate regional and age-related differences in the length of unemployment benefits. Disconnect health-insurance entitlement from unemployment registration. Tighten job-search requirements. Enforce the provision that a suitable job offer is not restricted to the occupational field of the unemployed person. Smooth pay increases by allowing a floor of $90 \%$ for the second year of people in their first job.

- Consider merging local labour offices with unemployment benefits and social assistance administration to create a one-stop shop and more fundamentally to integrate the management of those activities. Enhance coordination and automatic exchange of information between local labour offices, firms, assistance centres and education institutions. Expand the resources of public employment services to hire more high-skilled staff, and ensure that overall resources are better allocated to front-line placement tasks. Strengthen the umbrella function of the Ministry of Labour and Social Policy, including by promoting the adoption of best practices through performance management and the introduction of benchmarking of employment-service providers.

- $\quad$ Rationalise ALMPs by focusing more on job-search assistance, career guidance and work schemes having a high training content. Improve job-seeker profiling. Reduce passive social assistance by making more transfers (such as childcare subsidies) conditional in part on being employed or seeking work. Expand the scope of private employment services.

\section{Policies to deal with specific workforce groups}

- $\quad$ Develop child-care and long-term care facilities and pre-school education. Monitor closely the impact of the long maternity leave on the employment of mothers. Introduce an individual taxation system. Increase the female retirement age at a faster pace, e.g. to reach 67 by 2030 instead of 2040 as currently scheduled.

- Enhance work-based learning in VET programmes, and boost social partners' involvement. Expand subsidies to cover employers' VET costs. Elaborate a broad and flexible system of lifelong learning.

- $\quad$ Phase out all special occupational regimes, remove pre-retirement schemes, and avoid that disability pensions become attractive relative to old-age pensions. Promote the employment of people with disability by: reducing the employment quota of $6 \%$ and raising the penalty for firms failing to reach the revised level; and better training and activating workers with disability.

- Remove the prohibition to lay off a worker less than four years before retirement age.. 


\section{Bibliography}

Andrews, D., A. Caldera Sánchez and Å. Johansson (2011a), "Housing Markets and Structural Policies in OECD countries", OECD Economics Department Working Papers, No. 836, OECD Publishing.

Andrews, D., A. Caldera Sánchez and Å. Johansson (2011b), "Towards a Better Understanding of the Informal Economy”, OECD Economics Department Working Papers, No. 873, OECD Publishing.

Baranowska, A., M. Gebel and I.E. Kotowska (2011), "The role of fixed-term contracts at labour market entry in Poland: stepping stones, screening devices, traps or search subsidies?", Work, employment and Society, Vol. 25, No. 4.

BERR (2012), International Review of Leave Policies and Related Research, P. Moss (ed.), Institute of Education University of London, Department for Business Enterprise \& Regulatory Reform.

Boulhol, H. and P. Sicari (2013a), "Labour market performance by age groups: a focus on France", OECD Economics Department Working Papers, No. 1027, OECD Publishing.

Boulhol, H. and P. Sicari (2013b), "Do the average level and dispersion of socio-economic background measures explain France's gap in PISA scores?", OECD Economics Department Working Papers, No. 1028, OECD Publishing.

Brzesinski, M. and K. Kostro (2010), "Income and consumption inequality in Poland, 1998-2008", Bank $i$ Kredyt, Vol. 41, No. 4.

Budnik, K.B. (2008), "Search Equilibrium with Migration: The Case of Poland”, National Bank of Poland Working Paper, No. 45.

Bühn, A., C. Montenegro and F. Schneider (2010), "New estimates for the shadow economies all over the world", International Economic Journal, Vol. 24, No. 4, pp. 443-61.

Chancellery of the Prime Minister (2011), Youth 2011, Poland, The Chancellery of the Prime Minister, Warsaw, October.

Dar, A. and Z. Tzannatos (1999), "Active Labor Market Programs: A Review of the Evidence from Evaluations”, Social Protection Discussion Paper, No. 9901, The World Bank, Washington, D.C.

Du Caju, P., E. Gautier, D. Momferatou and M. Ward-Warmedinger (2008), "Institutional Features of Wage Bargaining in 23 European Countries, the US and Japan”, ECB Working Papers, No. 974, December.

Égert, B. and Goujard, A. (2014), "Strengthening product market competition in Poland", OECD Economics Department Working Papers, forthcoming.

European Commission (2012a), Rural Development in the EU, Statistical and Economic Information Report 2012, December.

European Commission (2012b), Assessment of the 2012 national reform programme and convergence programme for Poland, Commission Staff Working Document, COM(2012)323. 
European Commission (2013), Assessment of the 2013 national reform programme and convergence programme for Poland, Commission Staff Working Document, COM(2013)371.

EWCO (2010), Lack of eagerness among employers to train employees, European Working Conditions Observatory, April.

Fiori, G., G. Nicoletti, S. Scarpetta and F. Schiantarelli (2012), "Employment Effects of Product and Labour Market Reforms: Are There Synergies?”, Economic Journal, Vol. 122, No. 558.

Fujita, M., P. Krugman, and A.J. Venables (1999), The Spatial Economy: Cities, Regions and International Trade, Cambridge: MIT Press.

Golinowska, S. and A. Sowa (2010), "Development of the long term care in post-socialist countries, International conference of evidence based policy in long term care", London School of Economics, 8-11 September, London.

Griffith, R., R. Harrison and G. Macartney (2007), "Product Market Reforms, Labour Market Institutions and Unemployment", Economic Journal, Vol. 117, No. 519.

Grotkowska, G. and U. Sztanderska (2008), "Labour market problems and public employment services capabilities - institutional aspects", Frankfurt (Oder), 18-19 April.

Heckman, J.J. (2008), “Schools, Skills, and Synapses”, NBER Working Papers, No. 14064.

Heckman, J.J. and P. Carneiro (2003), "Human Capital Policy", in Inequality in America: What Role for Human Capital Policy?, J. Heckman and A. Krueger (eds.), MIT Press, Cambridge, Mass.

Iglicka, K. and M. Ziolek-Skrzypczak (2010), “EU Membership Highlights Poland's Migration Challenges", Migration Information Source, September.

IMF (2012), “Republic of Poland: 2012 Article IV Consultation”, IMF Country Report, No. 12/162, July.

IMF (2013), "Republic of Poland: 2012 Article IV Consultation”, IMF Country Report, No. 13/219, July.

Ingham, H. and M. Ingham (2011), "Job creation and labour market flexibility: miracle or mirage on the Polsh labour market?", Industrial Relations Journal, Vol. 42, No. 4.

Jacobi, L. and J. Kluve (2007), "Before and After the Hartz Reforms: The Performance of Active Labour Market Policy in Germany”, Journal for Labour Market Research, Vol. 40, No. 1.

James, E. (2009), "Rethinking Survivor Benefits", World Bank, Social Protection and Labor Discussion Paper, No. 928.

Kaczmarczyk, P. (2012), "Labour market impacts of post-accession migration from Poland", Free Movement of Workers and Labour Market Adjustment: Recent Experiences form OECD counties and the European Union, Chapter 7, OECD Publishing.

Kaczmarczyk, P. and M. Okolski (2008), "Demographic and labour-market impacts of migration on Poland”, Oxford Review of Economic Policy, Vol. 24, No. 3.

Kaluzna, D. (2009), "Main Features of the Public Employment Service in Poland", OECD Social, Employment and Migration Working Papers, No. 80, OECD Publishing. 
Kierzenkowski, R. (2008), "Bridging the housing gap in Poland", OECD Economics Department Working Papers, No. 639, OECD Publishing.

Kwiatkiewicz, A. (2008), "Self-employment and bogus self-employment in the construction industry in Poland", Expert Report, Project carried out with the financial support of the European Commission.

Martin, J.P. and D. Grubb (2001), "What works and for whom: a review of OECD countries' experiences with active labour market policies", IFAU-Office of Labour Market Policy Evaluation, Working Paper, No. 14.

Martinez-Fernandez, C., T. Weyman, J. Perek-Bialas, I. Sagan, P. Szukalski and P. Stronkowski (2013), "Demographic Transition and an Aging Society: Implications for Local Labour Markets in Poland", OECD Local Economic and Employment Development (LEED) Working Papers, No. 2013/08. OECD Publishing.

Melo, P.C., D.J. Graham and R.B. Noland (2009), “A Meta-Analysis of Estimates of Urban Agglomeration Economies”. Regional Science and Urban Economics, No. 39.

Ministry of Labour and Social Policy (2008), Employment in Poland, Security on a flexible labour market, M. Bukowski (ed.), Department of Economic Analyses and Forecasts.

Mroz, B. (2010), "Migration into the Shadow: Unregistered Work in Poland", mimeo, Warsaw School of Economics.

Nurzynska, I. (2012), "The rural development policy in Poland, synthetic picture of the new policy implementation results", Agricultural Economics and Rural Development, New Series, Year IX, No. 2.

O’Brien, P. and W. Paczynski (2006), "Poland's education and training: boosting and adapting human capital", OECD Economics Department Working Papers, No. 495, OECD Publishing.

OECD (2006a), Fundamental Reform of Personal Income Tax, OECD Tax Policy Studies, OECD Publishing.

OECD (2006b), OECD Economic Surveys: Poland, OECD Publishing.

OECD (2006c), Sickness, Disability and Work: Breaking the Barriers, Norway, Poland and Switzerland, Vol. 1, OECD Publishing.

OECD (2007), OECD Reviews of Tertiary Education: Poland, OECD Publishing.

OECD (2008a), OECD Economic Surveys: Poland, OECD Publishing.

OECD (2008b), "Declaring Work or Staying Underground: Informal Employment in Seven OECD

Counties", Employment Outlook, Chapter 2, OECD Publishing.

OECD (2008c), Jobs for Youth: United Kingdom, OECD Publishing.

OECD (2009), Jobs for Youth: Poland, OECD Publishing.

OECD (2010a), OECD Economic Surveys: Poland, OECD Publishing. 
OECD (2010b), Learning for Jobs, Synthesis Report of the OECD Reviews of Vocational Education and Training, OECD Publishing.

OECD (2010c), Sickness, Disability and Work: Breaking the Barriers, OECD Publishing.

OECD (2011a), "Reducing barriers to parental employment", Doing Better for Families, Chapter 4, OECD Publishing.

OECD (2011b), Off to a Good Start? Jobs for Youth, OECD Publishing.

OECD (2012a), OECD Economic Surveys: Poland, OECD Publishing.

OECD (2012b), Activating Jobseekers, How Australia Does It, OECD Publishing.

OECD (2012c), Closing the Gender Gap: Act Now, OECD Publishing.

OECD (2013a), Going for Growth, OECD Publishing.

OECD (2013b), Employment Outlook, OECD Publishing.

OECD (2013c), "Detailed description of employment protection legislation, 2012-2013”, Employment Protection Database, http://www.oecd.org/els/emp/All.pdf.

OECD (2013d), It's All About People: Jobs, equality and trust, Meeting of the OECD Council at Ministerial Level, 29-30 May, OECD Publishing.

OECD (2013e), “Country Note: Poland”, Education at a glance, OECD Publishing, Paris.

OECD (2013f), Education at a glance, OECD Publishing, Paris.

OECD (2013g), “Giving Youth a Better Start: An Action Plan”, C(2013)49/REV1.

OECD (2014), Ageing and Employment Policies. Poland 2014. Working Better with Age, OECD Publishing, forthcoming.

Okolski, M. and I. Topinska (2012), "Social Impact of Emigration and Rural-Urban Migration in Central and Eastern Europe", Final Country Report, Poland, On behalf of the European Commission, DG Employment, Social Affairs and Inclusion, April.

PNB (2013), "Mecina: Time to Give Jobless a Real Chance", Interview with Deputy Labour Minister Jacek Mecina, Polish News Bulletin, Economic Review, 29 March.

Polakowski, M. (2012), Youth Unemployment in Poland, Friedrich Ebert Stiftung Study, November.

Quintini, G., J.P. Martin and S. Martin (2007), "The Changing Nature of the School-to-Work Transition Process in OECD Countries", IZA Discussion Paper, No. 2582.

Rutkowski, J. (2011), "Skills for Productivity and Competitiveness: The Employers' Perspective", Europe 2020 Poland: Fueling Growth and Competitiveness in Poland Through Employment, Skills and Innovation, Chapter 3, Technical Report, The World Bank. 
RWI (2005), "Study on the effectiveness of ALMPs", Research project for the European Commission, DG Employment, Social Affairs and Equal Opportunities, Final Report, 22 December.

Schneider, F. (2013), "Size and Development of the Shadow Economy of 31 European and 5 other OECD Countries from 2003 to 2013: A Further Decline", mimeo.

Trappmann, V. (2011), "Precarious employment in Poland - a legacy of transition or an effect of European integration?", Emecon, Vol. 1/2011.

Venn, D. (2012), "Eligibility Criteria for Unemployment Benefits: Quantitative Indicators for OECD and EU countries", OECD Social, Employment and Migration Working Papers, No. 131, OECD Publishing.

Walewski, M. (2011), "An Attempt to Measure the Trends in Shadow Employment in Poland", World Bank Policy Research Paper, No. 5910.

World Bank (2013), Doing Business 2014, Economy Profile: Poland, World Bank Group, Washington, D.C.

World Economic Forum (2013), Global Competitiveness Report 2013-2014, World Economic Forum, Geneva.

Zientara, P. (2008), “A Report on the Polish Labor Market: An Insider-Outsider System”, Industrial Relations, Vol. 47, No. 3. 
ECO/WKP(2014)20

\section{WORKING PAPERS}

The full series of Economics Department Working Papers can be consulted at www.oecd.org/eco/workingpapers

1123. Enhancing competition and the business environment in Hungary

(June 2014) by Alvaro Pina

1122. Tackling labour mismatches and promoting mobility in Hungary

(June 2014) by Stéphane Sorbe

1121. Local public finances and municipal reform in Finland

(June 2014) by Christophe André and Clara Garcia

1120. The economic consequences of ageing: the case of Finland

(June 2014) by Christine de la Maisonneuve, Christophe André, Clara Garcia and Vincent Koen

1119. Making the most of skills in Denmark

(June 2014) by Stéphanie Jamet and Vincent Koen

1118. Trade specialisation and policies to foster competition and innovation in Denmark

(June 2014) by Müge Adalet McGowan

1117. Policies for making the Chilean labour market more inclusive

(June 2014) by Aida Caldera Sanchez

1116. Spillover effects from exiting highly expansionary monetary policies

(May 2014) by Łukasz Rawdanowicz, Romain Bouis, Jérôme Brezillon, Ane Kathrine Christensen and Kei-Ichiro Inaba

1115. Economic policies and microeconomic stability: a literature review and some empirics

(April 2014) by Paula Garda and Volker Ziemann

1114. How to improve Israel's health-care system

(April 2014) by Philip Hemmings

1113. How to improve taxes and transfers in Israel

(April 2014) by Philip Hemmings

1112. New evidence on the determinants of industrial specialisation (April 2014) by Asa Johansson and Eduardo Olaberria

1111. Economic growth from the household perspective: GDP and income distribution developments across OECD countries

(April 2014) by Orsetta Causa, Sonia Araujo, Agnès Cavaciuti, Nicolas Ruiz and Zuzana Smidova

1110. Would a growth slowdown in emerging markets spill over to high-income countries? A quantitative assessment (April 2014) By Patrice Ollivaud, Elena Rusticelli and Cyrille Schwellnus 
1109. Short-term indicator models for quarterly GDP growth in the BRIICS: A small-scale bridge model approach

(April 2014) by Thomas Chalaux and Cyrille Schwellnus

1108. The prudential regulation of financial institutions: why regulatory responses to the crisis might not prove sufficient

(March 2014) by William R. White

1107. OECD forecasts during and after the financial crisis: a post mortem

(March 2014) by Nigel Pain, Christine Lewis, Thai-Thanh Dang, Yosuke Jin and

Pete Richardson

1106. Fairly sharing the social impact of the crisis in Greece

(January 2014) by Vassiliki Koutsogeorgopoulou, Manos Matsaganis, Chrysa Leventi and Jan-David Schneider

1105. Dividing the pie in Brazil: income distribution, social policies and the new middle class (January 2014) by Jens M. Arnold and João Jalles

1104. New indicators of competition law and policy in 2013 for OECD and non-OECD countries (December 2013) by Enrico Alemani, Caroline Klein, Isabell Koske, Cristiana Vitale and Isabelle Wanner

1103. The effect of government debt, external debt and their interaction on OECD interest rates (December 2013) by David Turner and Francesca Spinelli

1102. The state of the banking sector in Europe

(December 2013) by Dirk Schoenmaker and Toon Peek

1101. Getting Irish youth on the job track

(December 2013) by Alberto González Pandiella

1100. New econometric estimates of long-term growth effects of different areas of public spending (December 2013) by Omar Barbiero and Boris Cournède

1099. Cross-country spillovers from fiscal consolidations

(December 2013) by Antoine Goujard

1098. Informal employment in Russia: definitions, incidence, determinants and labour market segmentation

(December 2013) by Hartmut Lehmann and Anzelika Zaiceva

1097. Capacity needs in the automobile industry in the short- to medium run (November 2013) by Caroline Klein and Isabell Koske

1096. Environmental policies and productivity growth - a critical review of empirical findings (November 2013) by Tomasz Koźluk and Vera Zipperer

1095. Green growth challenges and the need for an energy reform in Mexico (November 2013) by Carla Valdivia de Richter 